Prepared in cooperation with the Lansing Board of Water and Light and the Lansing Wellhead Protection Team

\title{
Preliminary Investigation of Groundwater Quality near a Michigan Cemetery, 2016-17
}

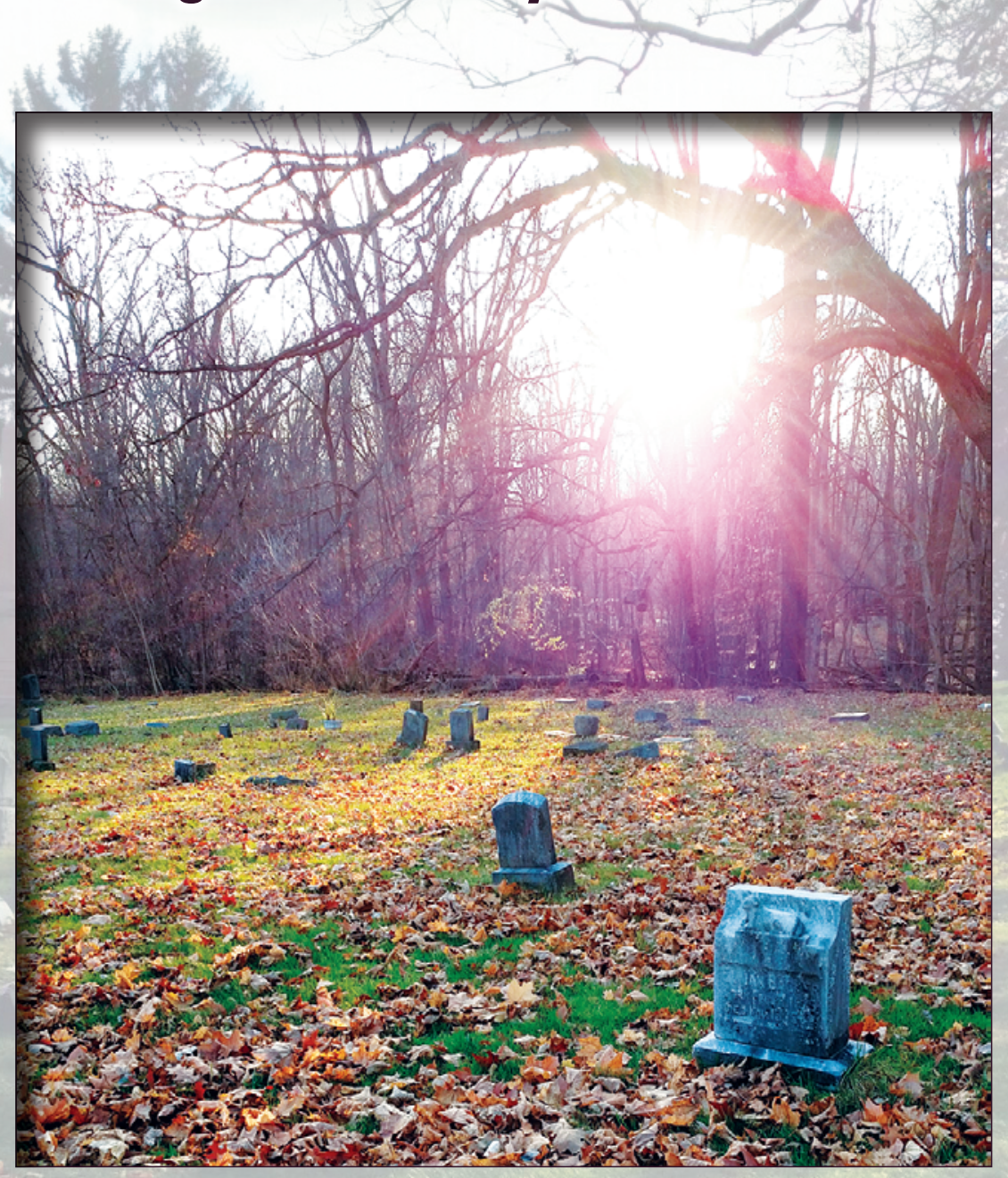

Scientific Investigations Report 2018-5120 
Cover. Inset photograph of area near monitoring well C3, Mt. Hope Cemetery, Lansing, Michigan. Background photograph showing Mt. Hope Cemetery (looking south). Photographs by Angela Brennan, U.S. Geological Survey. 


\section{Preliminary Investigation of Groundwater Quality near a Michigan Cemetery, 2016-17}

By Angela K. Brennan, Carrie E. Givens, Julia G. Prokopec, and

Christopher J. Hoard

Prepared in cooperation with the Lansing Board of Water and Light and the Lansing Wellhead Protection Team

Scientific Investigations Report 2018-5120 


\section{U.S. Department of the Interior \\ RYAN K. ZINKE, Secretary}

\section{U.S. Geological Survey James F. Reilly II, Director}

\section{U.S. Geological Survey, Reston, Virginia: 2018}

For more information on the USGS - the Federal source for science about the Earth, its natural and living resources, natural hazards, and the environment-visit https://www.usgs.gov or call 1-888-ASK-USGS.

For an overview of USGS information products, including maps, imagery, and publications, visit https://store.usgs.gov.

Any use of trade, firm, or product names is for descriptive purposes only and does not imply endorsement by the U.S. Government.

Although this information product, for the most part, is in the public domain, it also may contain copyrighted materials as noted in the text. Permission to reproduce copyrighted items must be secured from the copyright owner.

Suggested citation:

Brennan, A.K, Givens, C.E., Prokopec, J.G., and Hoard, C.J., 2018, Preliminary investigation of groundwater quality near a Michigan cemetery, 2016-17: U.S. Geological Survey Scientific Investigations Report 2018-5120, 23 p., https://doi.org/10.3133/sir20185120.

ISSN 2328-0328 (online) 


\section{Contents}

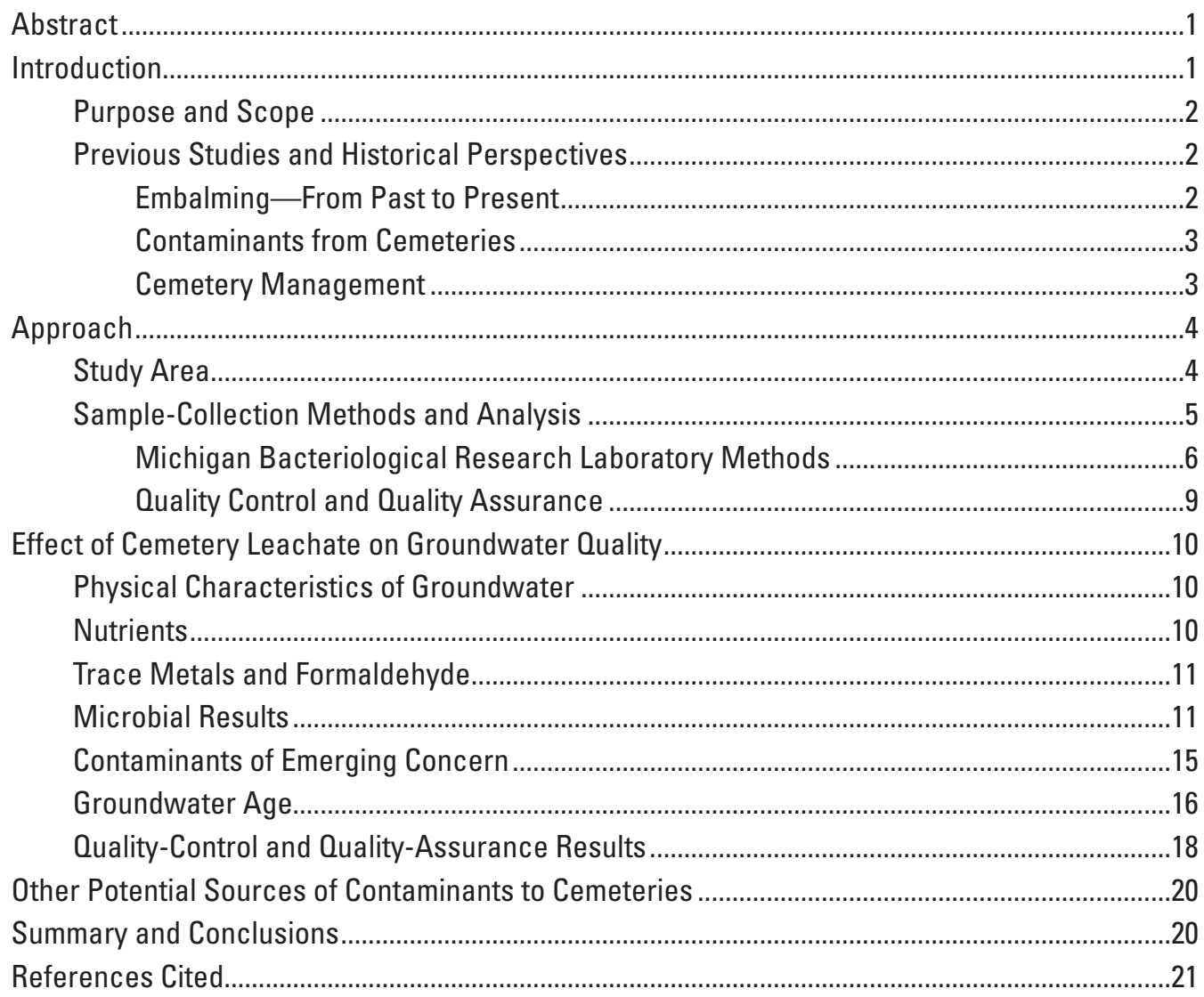




\section{Figures}

1. Map showing location of Mt. Hope Cemetery and sampling locations, Ingham County, Michigan, 2016-17.

2. Boxplots showing distribution of nutrient concentrations in groundwater samples by well, Mt. Hope Cemetery, Lansing, Michigan, 2016-17.

3. Graphs showing concentrations of indicator bacteria in groundwater samples collected near Mt. Hope Cemetery, Lansing, Michigan, 2016-17..

4. Aerial photograph and schematic diagrams showing conceptualization of groundwater flow and groundwater age near Mt. Hope Cemetery, Lansing, Michigan, 2016-17

\section{Tables}

1. U.S. Geological Survey observation wells near Mt. Hope Cemetery, Lansing, Michigan, 2016-17

2. Microbial growth conditions for target organisms, Mt. Hope Cemetery, Lansing, Michigan, 2016-17

3. Target bacterial pathogen genes and corresponding gene product, target organism, and Polymerase Chain Reaction primers, Mt. Hope Cemetery, Lansing, Michigan, 2016-17

4. Physical characteristics of groundwater samples, Mt. Hope Cemetery, Lansing, Michigan, 2016-17.

5. Trace-metal concentrations in groundwater samples, Mt. Hope Cemetery, Lansing, Michigan, 2016-17, data quartiles, and U.S. Environmental Protection Agency drinking-water standards and health-advisory criteria

6. Occurrence of microbial pathogen and antibiotic resistance genes in groundwater samples, Mt. Hope Cemetery, Lansing, Michigan, 2016-17.

7. Contaminants of emerging concern detected in groundwater samples, Mt. Hope Cemetery, Lansing, Michigan, 2016-17.

8. Relative percent difference in constituent concentrations for replicate samples, Mt. Hope Cemetery, Lansing, Michigan, 2016-17...

9. Quality-control sample results, Mt. Hope Cemetery, Lansing, Michigan, 2016-17 ........19 


\section{Conversion Factors}

U.S. customary units to International System of Units

\begin{tabular}{|c|c|c|}
\hline Multiply & By & To obtain \\
\hline \multicolumn{3}{|c|}{ Length } \\
\hline foot $(\mathrm{ft})$ & 0.3048 & meter $(\mathrm{m})$ \\
\hline \multicolumn{3}{|c|}{ Area } \\
\hline acre & 4,047 & square meter $\left(\mathrm{m}^{2}\right)$ \\
\hline acre & 0.4047 & hectare (ha) \\
\hline acre & 0.4047 & square hectometer $\left(\mathrm{hm}^{2}\right)$ \\
\hline acre & 0.004047 & square kilometer $\left(\mathrm{km}^{2}\right)$ \\
\hline
\end{tabular}

Temperature in degrees Celsius $\left({ }^{\circ} \mathrm{C}\right)$ may be converted to degrees Fahrenheit $\left({ }^{\circ} \mathrm{F}\right)$ as follows:

$$
{ }^{\circ} \mathrm{F}=\left(1.8 \times{ }^{\circ} \mathrm{C}\right)+32 \text {. }
$$

\section{Datum}

Vertical coordinate information is referenced to the North American Vertical Datum of 1988 (NAVD 88).

Horizontal coordinate information is referenced to the North American Datum of 1983 (NAD 83).

\section{Supplemental Information}

Specific conductance is given in microsiemens per centimeter at 25 degrees Celsius $(\mu \mathrm{S} / \mathrm{cm}$ at $\left.25^{\circ} \mathrm{C}\right)$.

Concentrations of chemical constituents in water are given in either milligrams per liter (mg/L) or micrograms per liter $(\mu \mathrm{g} / \mathrm{L})$.

Concentrations of microbial constituents in water are given in colony forming units per 100 milliliters (CFU/100 mL) or most probable number per 100 milliliters (MPN/100 mL). 


\section{Abbreviations}

\begin{tabular}{|c|c|}
\hline CECs & contaminants of emerging concern \\
\hline CFC & chlorofluorocarbon \\
\hline CFU & colony forming units \\
\hline DNA & deoxyribonucleic acid \\
\hline E. coli & Escherichia coli \\
\hline EPA & U.S. Environmental Protection Agency \\
\hline FIB & fecal indicator bacteria \\
\hline LHA & lifetime health advisory \\
\hline MCL & maximum contaminant level \\
\hline MI-BaRL & Michigan Bacteriological Research Laboratory \\
\hline $\mathrm{mg} / \mathrm{L}$ & milligrams per liter \\
\hline$\mu \mathrm{g} / \mathrm{L}$ & micrograms per liter \\
\hline$\mu \mathrm{L}$ & microliters \\
\hline MRSA & methicillin-resistant Staphylococcus aureus \\
\hline NWIS & National Water Information System \\
\hline NWQL & National Water Quality Laboratory \\
\hline PBDEs & polybrominated diphenyl ethers \\
\hline PBS & phosphate buffer solution \\
\hline PCR & polymerase chain reaction \\
\hline RL & reporting limit \\
\hline RNA & ribonucleic acid \\
\hline RPD & relative percent difference \\
\hline S. aureus & Staphylococcus aureus \\
\hline $\mathrm{SF}_{6}$ & sulfur hexafluoride \\
\hline SMCL & secondary maximum contaminant level \\
\hline sp. & species \\
\hline spp. & several species \\
\hline U.K. & United Kingdom \\
\hline U.S. & United States \\
\hline USGS & U.S. Geological Survey \\
\hline WHO & World Health Organization \\
\hline WHPA & Wellhead Protection Area \\
\hline WHPP & Wellhead Protection Program \\
\hline
\end{tabular}




\title{
Preliminary Investigation of Groundwater Quality near a Michigan Cemetery, 2016-17
}

\author{
By Angela K. Brennan, Carrie E. Givens, Julia G. Prokopec, and Christopher J. Hoard
}

\section{Abstract}

The potential effect of cemetery leachate on groundwater quality in the United States has rarely been studied. Nutrients and other constituents associated with decomposition and burial processes (such as embalming) have the potential to reach shallow groundwater and could affect nearby drinkingwater sources. The objective of this preliminary investigation was to evaluate the potential effect of cemetery leachate on shallow groundwater quality near Mt. Hope Cemetery in Ingham County, Lansing, Michigan, which is within the Wellhead Protection Area for the City of Lansing. The constituents measured in this study include nutrients, trace metals, formaldehyde, fecal indicator bacteria, bacterial pathogen genes, contaminants of emerging concern (including pharmaceuticals, personal care products, and wastewater indicator compounds), and age-dating compounds. Three monitoring wells were installed 7 to 12 feet below land surface downgradient from the cemetery and sampled quarterly for 1 year. A fourth well (Fenner) was sampled to determine groundwater conditions outside the potential effects of cemetery leachate; samples from this well were collected near the water table.

Nitrogen and phosphorus compounds were present at higher concentrations in two of the three monitoring wells (wells $\mathrm{C} 1$ and $\mathrm{C} 3$ ) than in the Fenner well. Formaldehyde and pharmaceuticals were not detected in any of the wells; however, several trace metals, including arsenic, manganese, and aluminum, were present in high concentrations, with arsenic concentrations typically exceeding the U.S. Environmental Protection Agency (EPA) drinking-water standard. Several wastewater indicator compounds, including atrazine, phenol, p-cresol, camphor, and skatole, were detected in the monitoring wells. Microbial data indicate the presence of staphylococci, enterococci, and Escherichia coli (E. coli), with the highest concentrations being measured in the same two monitoring wells that exhibited elevated concentrations of nutrients in the groundwater (wells C1 and C3). Several bacterial pathogen genes were detected, including several Enterococcus species (spp.)—vanB (vancomycin-resistant enterococci), shiga-toxin-producing $E$. coli genes (including eaeA [attachment virulence trait] and $s t x 1$ [moderate toxin]), and the E. coli 16s ribosomal RNA (rDNA) gene (E. coli species marker). These results were similar to results of studies conducted in Canada, Australia, and the United Kingdom, in which concentrations of bacteria, metals, and nutrients were elevated in groundwater near cemeteries.

\section{Introduction}

Although nutrients and other constituents associated with decomposition and burial processes (such as embalming) have the potential to reach shallow groundwater and could affect nearby drinking-water sources, the effect of cemetery leachate on groundwater quality in the United States has rarely been studied. Therefore, the U.S. Geological Survey (USGS), in cooperation with the Lansing Board of Water and Light and the Lansing Wellhead Protection Team, developed a study to evaluate the potential effect of cemetery leachate on groundwater quality through reconnaissance sampling and analysis of groundwater samples to test for possible environmental and human-health concerns associated with cemetery leachate. This study was conducted near Mt. Hope Cemetery in Lansing, Michigan, which is within the Lansing Wellhead Protection Area (WHPA) in Ingham County, Michigan. One of the elements of a wellhead protection plan is to inventory sites of known or potential contamination within a WHPA (Michigan Department of Environmental Quality, 2006). Historically, cemeteries in Michigan have not been included in the Wellhead Protection Program (WHPP) contaminant-source inventories. The constituents analyzed for in this study include nutrients, trace metals, formaldehyde, fecal indicator bacteria (FIB), bacterial pathogen genes, contaminants of emerging concern (CECs) (including pharmaceuticals, personal care products, and wastewater indicator compounds), and agedating compounds.

The USGS provides reliable scientific information to describe complex water quality conditions and the connection with hydrologic systems and assists in understanding their effects on the public and the environment. In most instances, this involves documenting and analyzing the effects of widely recognized phenomena such as surface-water and groundwater quality and flow. On occasion, this involves relatively smallscale studies of previously unrecognized phenomena, such as evaluating the potential effect of cemeteries on groundwater 
quality that may affect nearby drinking-water resources. The USGS works within its strategic science direction and with its cooperative partners, such as the Lansing Board of Water and Light, to document these possible emerging hazards and to ensure that scientific methods are applied effectively to better understand these phenomena and thereby protect drinkingwater supplies.

\section{Purpose and Scope}

This report documents the results of analyses of 21 samples (including quality-control samples) collected approximately quarterly from three monitoring wells and one well outside the potential effects of cemetery leachate near Mt. Hope Cemetery in Lansing, Michigan, from December 2016 to July 2017. Samples were analyzed for nutrients, trace metals, formaldehyde, FIB, bacterial pathogen genes, contaminants of emerging concern CECs (including pharmaceuticals, personal care products, and wastewater indicator compounds), and agedating compounds. Four samples were collected in January 2017 for groundwater age dating.

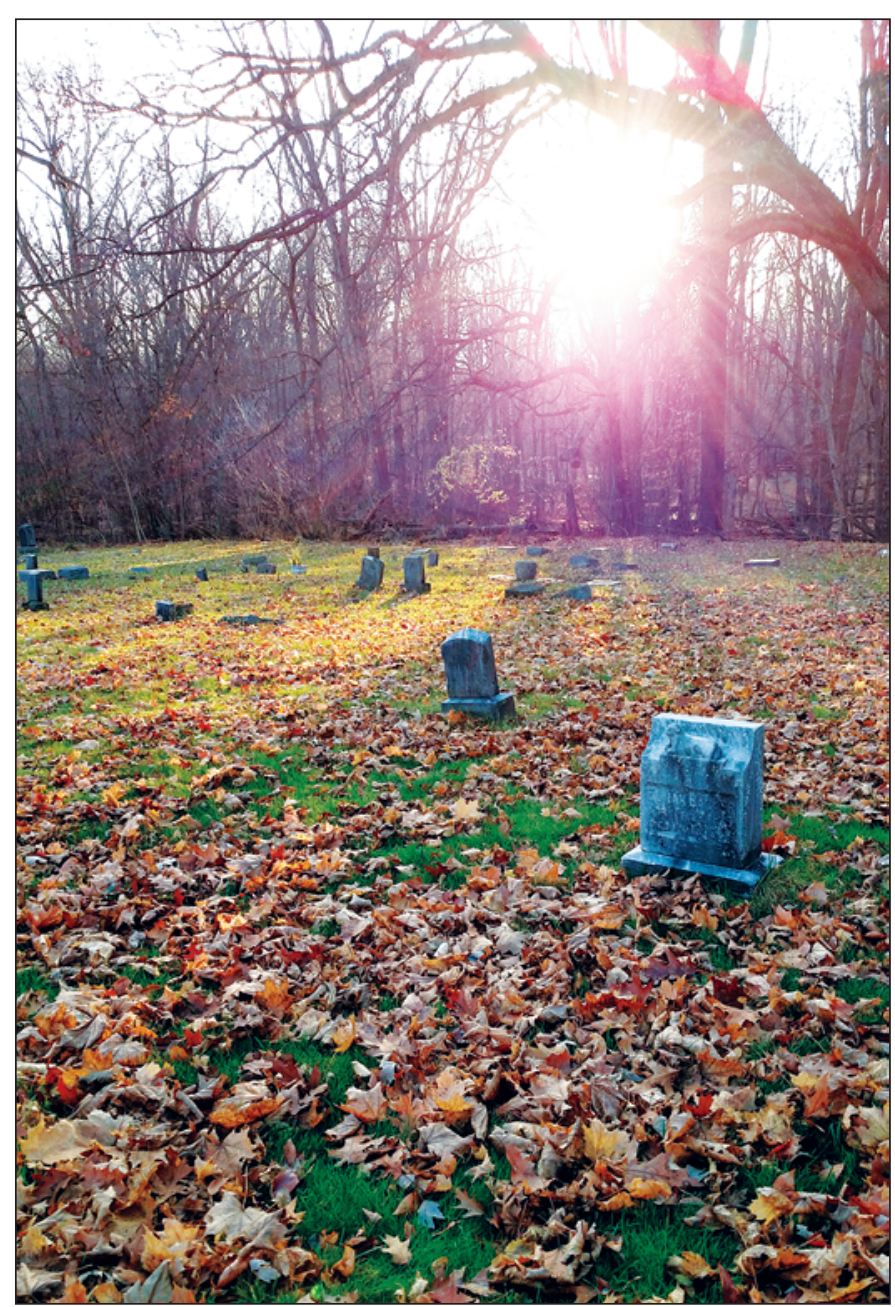

Area near monitoring well C3, Mt. Hope Cemetery, Lansing, Michigan. Photograph by Angela Brennan, U.S. Geological Survey.

\section{Previous Studies and Historical Perspectives}

Several international studies have been published on the effect of cemetery leachate on groundwater quality, including research from Australia, Canada, Germany, South Africa, and the United Kingdom (U.K.); however available data on the potential effect of cemetery leachate on water resources in the United States (U.S.) are limited. Results of these studies indicated that cemeteries can affect the presence and concentration of certain bacteria, nutrients, and metals in groundwater (Dent and Knight, 1998; Engelbrecht, 1998; Ücisik and Rushbrook, 1998; Young and others, 2002), and that large quantities of nutrients and constituents associated with burial processes (such as embalming) can leach into shallow groundwater and potentially threaten nearby drinking-water sources. The Midland Agency Region (U.K.) and the World Health Organization (WHO) suggest that cemeteries may pose a microbial problem requiring further study and should be viewed as being comparable to individual septic tanks (Young and others, 2002) or a special type of landfill (Ücisik and Rushbrook, 1998).

Burial processes, from preservation to interment, have changed throughout history and can vary with geographic region, religion, local ordinance, economic status, and other factors. Soil type, precipitation, and groundwater levels vary with geography. Religious practices can affect whether or not to embalm, and whether to use modern caskets or a shroud. Local ordinances may govern the depth of interment and guide the design and layout of cemeteries, whereas socioeconomics plays a role in determining the type of casket, the burial process, and even the burial location (cemetery plot or the burial of cremated remains) (Young and others, 2002). Potential sources of contamination to shallow groundwater in and near cemeteries regardless of the burial practices and processes include decomposition, embalming chemicals, memorial markers, cemetery grounds maintenance, cemetery road maintenance, and vehicle usage (Dent, 2002).

\section{Embalming-From Past to Present}

In the U.S., modern embalming for the purpose of performing a funeral is believed to have begun in the 1860 s during the American Civil War. The purpose of modern embalming was to preserve the body until it could be transported home for burial, and to prevent the spread of infectious diseases (Brenner, 2014). From the 1860s to about 1900, arsenic and mercury were the primary chemicals used in embalming solutions (Spongberg and Becks, 2000). Phenol was introduced in the mid-19th century and was commonly mixed with glycerine (Brenner, 2014). The human and environmental health risks associated with these early embalming substances were eventually realized, resulting in the current use of formaldehyde (Spongberg and Becks, 2000). The use of alternative replacements for formaldehyde, including a solution made of ethanol, glycerine, and thymol and another composed of diethylene glycol and monoethylene glycol, is becoming more 
common in the funeral industry (Brenner, 2014). In the U.S., embalming fluids currently (2018) are exempt from regulation as pesticides by the Federal Insecticide, Fungicide, and Rodenticide Act (U.S. Environmental Protection Agency, 2014a).

\section{Contaminants from Cemeteries}

Chemical constituents, bacteria, and viruses are some of the main concerns associated with burial processes (Young and others, 2002; Dent, 2002). Other contaminants attributed to the burial process can result from the decomposition of caskets, upholstery fabrics, clothing, metal dental fillings, medical devices, jewelry, and other funeral artifacts. The constituents evaluated as part of this study can be derived from sources related to the funeral process, including chemicals associated with embalming, human decomposition, and decomposition of caskets, fabrics, and other burial objects; and chemicals used in the maintenance of cemetery grounds. In this project, the presence and concentrations of several possible constituents related to these sources, including nutrients, trace metals, formaldehyde, FIB, bacterial pathogen genes, and CECS (pharmaceuticals, personal care products, and wastewater indicator compounds) were evaluated. According to Young and others (2002), few studies have included monitoring groundwater near cemeteries for microbes. These microbial studies showed an increase in bacteria including fecal coliforms, Escherichia coli (E. coli), enterococci, and Staphylococcus aureus (S. aureus) in groundwater within and near cemeteries (Engelbrecht, 1998; Rodrigues and Pacheco, 2010). FIB and bacterial pathogens are a concern for human health as these bacteria and pathogens may leave the cemetery boundaries through groundwater transport. Depending on environmental conditions (for example, $\mathrm{pH}$, temperature, and organic-matter content), bacteria can survive and proliferate within the soil and groundwater, and the elevated nutrient concentrations found in cemetery leachate may further enrich these bacterial communities (Engelbrecht, 1998; Rodrigues and Pacheco, 2010).

\section{Cemetery Management}

Unknowingly, many cemetery managers are already applying at least one management practice, called "phytoremediation" (the use of trees and deep-rooted plants to remediate contaminants in the soil and groundwater), to address the potential for contaminants to leave the cemetery property (Dent and Knight, 1998). In addition to phytoremediation, other management practices could include (1) establishing buffer zones around the perimeter of cemeteries; (2) properly assessing and managing the placement of new cemeteries and extensions, and taking into consideration the hydrogeologic settings of the land; (3) minimizing irrigation and fertilizer use; and (4) positioning interments in time and location within the cemetery to distribute contaminants and reduce point loading (Dent and Knight, 1998).



Mt. Hope Cemetery (looking south), Lansing, Michigan. Photograph by Angela Brennan, U.S. Geological Survey. 


\section{Approach}

This study was conducted from December 2016 to July 2017 at Mt. Hope Cemetery, Ingham County, Michigan, which is situated within the Lansing Wellhead Protection Area (fig. 1). Mt. Hope Cemetery is managed by the City of Lansing Parks and Recreation Department, and burials still actively occur within the cemetery grounds.

\section{Study Area}

Mt. Hope Cemetery, an 82-acre facility in the City of Lansing, is bordered on the west by Sycamore Creek (fig. 1) (Luukkonen, 2014). The cemetery opened in 1874, even though some of the markers predate that year and represent where people from smaller local cemeteries were exhumed from other locations and reinterred at Mt. Hope Cemetery.
A numerical groundwater flow model published by the USGS in 2009 indicates that regional groundwater flow (Ingham County, Lansing, Michigan) is generally from south to north and from southeast to northwest, and that local flow is generally toward rivers (Luukkonen, 2010). At Mt. Hope Cemetery, regional and local groundwater flow is generally from east to west toward Sycamore Creek (fig. 1).

The study area generally consists of glacial drift overlying undifferentiated Pennsylvanian-age sandstone of the Saginaw Formation. The glacial drift is classified as mediumtextured till (Farrand and Bell, 1982), which is a dominantly loam or silt-loam matrix that includes boulders, cobbles, and other sediments ranging in size from clay to gravel. This heterogeneous mix of geologic material affects the flow of groundwater, and the constituents it contains, through the subsurface. The Saginaw Formation is composed primarily of sandstone and shale with smaller amounts of coal and limestone (Vanlier and others, 1973). Depth to bedrock near the cemetery is approximately 40 to 50 feet $(\mathrm{ft})$ below land surface



Figure 1. Location of Mt. Hope Cemetery and sampling locations, Ingham County, Michigan, 2016-17. 
and approximately $790 \mathrm{ft}$ above NAVD 88 (Luukkonen, 2010). The elevation of land surface in the cemetery ranges from 830 to $880 \mathrm{ft}$ above NAVD 88 (fig. 1); therefore, the thickness of the glacial drift ranges approximately from 40 to $90 \mathrm{ft}$. The glacial drift directly under the cemetery has a very steep slope on the west side of the cemetery where it borders Sycamore Creek. It is assumed that a local groundwater flow path for water that recharges in the cemetery has a component following this steep gradient toward the west to Sycamore Creek.

Three USGS monitoring wells (C1, C2, and C3) were installed west of Mt. Hope Cemetery, and an existing USGS monitoring well east of Mt. Hope Cemetery (Fenner) was used to represent groundwater conditions outside the potential effects of cemetery leachate. Wells $\mathrm{C} 1, \mathrm{C} 2$, and C3 were located approximately 14,41 , and $20 \mathrm{ft}$, respectively, from the boundary of Mt. Hope Cemetery. The three USGS monitoring wells were installed in glacial drift at depths ranging from 7 to $12 \mathrm{ft}$ below land surface. The Fenner well is open to the Saginaw Formation (from 51 to $215 \mathrm{ft}$ below land surface) and contains groundwater in sandstone underlying the Fenner Nature Center (historically Fenner Arboretum). The Fenner well is surrounded by forest and grassland and is about $930 \mathrm{ft}$ east of the eastern cemetery border (fig. 1). Groundwater was sampled from the Fenner well in the open part of the well bore just below the water table (table 1). The quality of water in the Fenner well represents groundwater conditions outside the potential effects of cemetery leachate (fig. 1).

\section{Sample-Collection Methods and Analysis}

The USGS collected samples approximately quarterly from December 2016 to July 2017 (not including age-dating sampling, which occurred in January 2017) to evaluate the potential effect of cemetery leachate on groundwater quality through reconnaissance sampling and analysis of groundwater samples to test for possible environmental and humanhealth concerns associated with cemetery leachate (table 1). The USGS collected samples with a peristaltic pump at sites $\mathrm{C} 1, \mathrm{C} 2$, and $\mathrm{C} 3$, and a submersible pump at the Fenner well (fig. 1). Groundwater samples to be analyzed for formaldehyde, trace metals, and CECs were collected in December 2016 and February 2017 (the first two sampling events). Because laboratory results for these constituents are typically not reported for several months after sample collection, sampling early in the project allowed sufficient time for analysis. Physical field characteristics, nutrient concentrations, and concentrations of FIB (total coliforms, fecal coliforms, E. coli, enterococci, and Staphylococcus) and bacterial pathogen genes (for pathogenic E. coli, Enterococcus, Salmonella, Shigella, and Staphylococcus) were measured in December 2016 and in February, May, and July 2017. A list of constituents analyzed for can be obtained by the USGS station number (table 1) at the USGS National Water Information System (NWIS) website at https://waterdata.usgs.gov/nwis (U.S. Geological Survey, 2017a).

Water-quality samples were collected in accordance with the USGS "National Field Manual for the Collection of Water-Quality Data" (National Field Manual) (U.S. Geological Survey, 2006). Samples were collected during base-flow

Table 1. U.S. Geological Survey observation wells near Mt. Hope Cemetery, Lansing, Michigan, 2016-17.

[USGS, U.S. Geological Survey; NAD 83, North American Datum of 1983; NAVD 88, North American Vertical Datum of 1988; ft, feet]

\begin{tabular}{|c|c|c|c|c|c|c|c|}
\hline $\mathrm{C} 1$ & 424240084314001 & $\begin{array}{l}\text { 04N 02W 27A01 } \\
\text { INGHAM CO } \\
(\mathrm{C}-1)\end{array}$ & $42^{\circ} 42^{\prime} 39.8^{\prime \prime}$ & $84^{\circ} 31^{\prime} 39.9^{\prime \prime}$ & 824.66 & 12.23 & 6.01 to 11.98 \\
\hline $\mathrm{C} 2$ & 424230084314101 & $\begin{array}{l}\text { 04N 02W 27A01 } \\
\text { INGHAM CO } \\
(\mathrm{C}-2)\end{array}$ & $42^{\circ} 42^{\prime} 30.1^{\prime \prime}$ & $84^{\circ} 31^{\prime} 40.6^{\prime \prime}$ & 822.05 & 6.98 & 5.50 to 6.73 \\
\hline Fenner & 424235084311201 & $\begin{array}{c}\text { 04N 02W 26BBDB } 01 \\
\text { INGHAM CO } \\
\text { (FENNER ARBORETUM) }\end{array}$ & $42^{\circ} 42^{\prime} 35^{\prime \prime}$ & $84^{\circ} 31^{\prime} 12^{\prime \prime}$ & 829.54 & 215 & $\begin{array}{l}\text { Cased to } 51 \mathrm{ft} \text {, } \\
\text { open in bedrock } \\
51 \text { to } 215 \mathrm{ft}\end{array}$ \\
\hline
\end{tabular}






Hydrologists collecting groundwater samples at well C1, Mt. Hope Cemetery, Lansing, Michigan. Groundwater samples were collected from four wells located near Mt. Hope Cemetery. Photograph by Angela Brennan, U.S. Geological Survey.

conditions in Sycamore Creek to attempt to limit the influence of surface water in the monitoring wells. Wells were purged before sampling to remove standing water. Wells were purged until field parameters stabilized, which indicates that the discharge water represents ambient formation water per USGS groundwater sampling methods (U.S. Geological Survey, 2006; Wilde and others, 2004). Field characteristics (specific conductance, $\mathrm{pH}$, temperature, dissolved-oxygen concentration) were monitored by using a calibrated multiparameter sonde in a sealed flow-through cell to verify that the groundwater had stabilized prior to sampling. Turbidity was monitored by collecting water samples from the flow-through cell and analyzing them with a portable field turbidimeter. Samples were stored on ice in coolers and shipped the day of collection by overnight delivery to the USGS National Water Quality Laboratory (NWQL) in Denver, Colorado, for determination of nutrients, trace metals, pharmaceuticals, and wastewater indicator compounds. Samples analyzed for formaldehyde were sent to RTI Laboratory in Livonia, Michigan. Samples to be analyzed for FIB and bacterial pathogen genes were hand delivered to the USGS Michigan Bacteriological Research Laboratory (MI-BaRL) in Lansing, Michigan.
Samples for determination of age-dating constituents (chlorofluorocarbons [CFCs], specifically CFC-11, -12, and -113); sulfur hexafluoride ( $\mathrm{SF}_{6}$ ); and associated dissolved gases) were collected on January 25, 2017, at each of the four wells. Samples were analyzed at the USGS Reston Age Dating Laboratory in Reston, Virginia. Samples for age-dating and analysis for dissolved gases were collected in accordance with protocols described by the USGS Reston Age Dating Laboratory (U.S. Geological Survey, 2017b).

Censored data values that were less than the laboratory reporting limit were treated as equal to the reporting limit for data computations and analysis, as well as figure and table calculations.

\section{Michigan Bacteriological Research Laboratory Methods}

Water samples were filtered at the MI-BaRL by using sterilized equipment and standard methods for membrane filtration (table 2). Samples were plated on selective media for enumeration or enrichment (table 2). 
Table 2. Microbial growth conditions for target organisms, Mt. Hope Cemetery, Lansing, Michigan, 2016-17.

[R2A, Reasoner's 2A agar; spp., several species; mFC, membrane fecal coliform agar; mTEC, membrane-thermotolerant Escherichia coli; PEA, phenylethyl alcohol agar; mEI, standard media used for membrane filtration method for measuring enterococci in water]
Target organism
Type
Growth medium
Reference

Heterotrophic bacteria $\quad$ Count R2A Reasoner and Geldreich, 1985

$\begin{array}{llrl}\text { Total coliforms } & \text { Count } & \text { American Public Health } \\ \text { Association, 2012 [9223B] }\end{array}$

\begin{tabular}{|c|c|c|c|}
\hline Fecal coliforms (Shigella spp.) & Count & $\mathrm{mFC}$ & $\begin{array}{l}\text { American Public Health } \\
\text { Association, } 2012 \text { [9222G] }\end{array}$ \\
\hline \multirow{2}{*}{ Escherichia coli } & Count & Colilert & $\begin{array}{l}\text { American Public Health } \\
\text { Association, } 2012 \text { [9223B] }\end{array}$ \\
\hline & Count & mod mTEC & $\begin{array}{l}\text { U.S. Environmental Protection } \\
\text { Agency, 2014b [1603] }\end{array}$ \\
\hline Salmonella spp. & Enrichment & $\begin{array}{c}\text { Rappaport Vassiliadis } \\
\text { R10 Broth }\end{array}$ & Vassiliadis and others, 1978 \\
\hline
\end{tabular}

Gram-positive cocci Count PEA Lilley and Brewer, 1953 $\begin{array}{ccc}\text { Enterococci } & \text { Count } & \text { U. S. Environmental Protection } \\ \text { Agency, 2009b [1600] }\end{array}$

Staphylococcus spp. Count Baird Parker American Public Health

Association, 2012 [9213D]

After bacteria counts from membrane filtration enumeration were recorded, all target and nontarget growth was subsequently used to detect the presence of pathogen or antibiotic resistance gene markers from target organisms (table 3). Sterile phosphate buffer solution (PBS) was used to wash and remove growth from the filter. All growth was transferred to a cryovial and additional 500 microliters $(\mu \mathrm{L})$ of 40-percent glycerol was added to create a glycerol stock. The resulting glycerol stocks were stored at $-70{ }^{\circ} \mathrm{C}$ until analysis. Glycerol stocks were thawed, homogenized, and $100 \mu \mathrm{L}$ (gram-negative cultures) or $400 \mu \mathrm{L}$ (gram-positive cultures) was used for deoxyribonucleic acid (DNA) extraction (Qiagen DNeasy DNA extraction kit; Qiagen, Valencia, California). DNA extraction blanks were included in every round of sample extractions. Extracted DNA was stored at $-20^{\circ} \mathrm{C}$ until polymerase chain reaction (PCR) analysis was performed. PCR was used to detect the presence of 11 bacterial gene markers for species identification and pathogenicity and antibiotic resistance capabilities (table 3). Standard quality-control checks of PCR reactions included running a positive and negative PCR control with every PCR run.

Cleaning of sample tubing was adjusted from standard USGS protocols after the first sample set was collected in December 2016 to address bacterial presence in field blanks. The new adjusted cleaning protocol was a 10-percent bleach rinse followed by a sterile-water rinse, which was incorporated following the inorganic-sample cleaning protocol recommended in the USGS National Field Manual (Wilde, 2004). 
Table 3. Target bacterial pathogen genes and corresponding gene product, target organism, and Polymerase Chain Reaction primers, Mt. Hope Cemetery, Lansing, Michigan, 2016-17.

[sp., species; F, forward primer; R, reverse primer; T, thymine; G, guanine; C, cytosine; A, adenine; E. coli, Escherichia coli; spp., several species]

\begin{tabular}{|c|c|c|c|c|c|}
\hline $\begin{array}{l}\text { Target } \\
\text { gene }\end{array}$ & $\begin{array}{c}\text { Gene } \\
\text { product }\end{array}$ & $\begin{array}{c}\text { Target } \\
\text { organism }\end{array}$ & $\begin{array}{l}\text { Positive } \\
\text { control }\end{array}$ & Primers & Reference \\
\hline$e s p$ & $\begin{array}{l}\text { Enterococcal surface } \\
\text { protein }\end{array}$ & $\begin{array}{l}\text { Enterococcus } \\
\text { sp. }\end{array}$ & E-53 & $\begin{array}{l}\text { F: TTGCTAATGCTAGTCCACGACC } \\
\text { R: GCGTCAACACTTGCATTGCCGAA }\end{array}$ & $\begin{array}{l}\text { Shankar and others, } \\
1999\end{array}$ \\
\hline vanA & $\begin{array}{l}\text { Acquired high level } \\
\text { of vancomycin } \\
\text { resistance }\end{array}$ & $\begin{array}{l}\text { Enterococcus } \\
\text { faecium }\end{array}$ & ATCC 700221 & $\begin{array}{l}\text { F: GGGAAAACGACAATTGC } \\
\text { R: GTACAATGCGGCCGTTA }\end{array}$ & $\begin{array}{l}\text { Dutka-Malen and } \\
\text { others, } 1995\end{array}$ \\
\hline $\operatorname{van} B$ & $\begin{array}{l}\text { Acquired intermedi- } \\
\text { ate level of vanco- } \\
\text { mycin resistance }\end{array}$ & $\begin{array}{l}\text { Enterococcus } \\
\text { faecalis }\end{array}$ & ATCC 51299 & $\begin{array}{l}\text { F: ATGGGAAGCCGATAGTC } \\
\text { R: GATTTCGTTCCTCGACC }\end{array}$ & $\begin{array}{l}\text { Dutka-Malen and } \\
\text { others, } 1995\end{array}$ \\
\hline stxl & Shiga toxin 1 & E. coli & ATCC 35150 & $\begin{array}{l}\text { F: ACACTGGATGATCTCAGTGG } \\
\text { R: CTGAATCCCCCTCCATTATG }\end{array}$ & $\begin{array}{l}\text { Duris and others, } \\
2009\end{array}$ \\
\hline stx 2 & Shiga toxin 2 & E. coli & ATCC 35150 & $\begin{array}{l}\text { F: CCATGACAACGGACAGCAGTT } \\
\text { R: CCTGTCAACTGAGCAGCACTTTG }\end{array}$ & $\begin{array}{l}\text { Duris and others, } \\
2009\end{array}$ \\
\hline$s p v C$ & $\begin{array}{l}\text { Salmonella plasmid } \\
\text { of virulence }\end{array}$ & $\begin{array}{l}\text { Salmonella } \\
\text { spp. }\end{array}$ & ATCC 14028 & $\begin{array}{l}\text { F: CTCCTTGCACAACCAAATGCGGA } \\
\text { R: GTCTTCTGCATTTCGCCACCATCA }\end{array}$ & Chiu and $\mathrm{Ou}, 1996$ \\
\hline$i p a H$ & $\begin{array}{l}\text { Invasion plasmid } \\
\text { antigen } \mathrm{H}\end{array}$ & Shigella sonnei & ATCC 9290 & $\begin{array}{l}\text { F: GTTCTTGACCGCCTTTCCGATA } \\
\text { R: GCCGGTCAGCCACCCTC }\end{array}$ & $\begin{array}{l}\text { Islam and others, } \\
1993\end{array}$ \\
\hline fem $A$ & $48 \mathrm{kD}$ protein & $\begin{array}{l}\text { Staphylococcus } \\
\text { aureus }\end{array}$ & ATCC 43300 & $\begin{array}{l}\text { F: AAAAAAGCACATAACAAGCG } \\
\text { R: GATAAAGAAGAAACCAGCAG }\end{array}$ & $\begin{array}{l}\text { Mehrotra and } \\
\text { others, } 2000\end{array}$ \\
\hline mecA & $\begin{array}{l}\text { Penicillin binding } \\
\text { protein } 2 \mathrm{~A}\end{array}$ & $\begin{array}{l}\text { Staphylococcus } \\
\text { aureus } \\
\text { (methicillin } \\
\text { resistance) }\end{array}$ & ATCC 43300 & $\begin{array}{l}\text { F: CAAGATATGAAGTGGTAAATGGT } \\
\text { R: TTTACGACTTGTTGCATACCATC }\end{array}$ & $\begin{array}{l}\text { Reischl and others, } \\
2000\end{array}$ \\
\hline
\end{tabular}




\section{Quality Control and Quality Assurance}

From December 2016 to July 2017, four sequential replicate samples were collected to assess for nutrients, FIB, and bacterial pathogen genes, and two replicates were collected for analysis for formaldehyde, trace metals, and CECs. Field replicate data are reported as relative percent difference (RPD). RPD was calculated for constituents by using equation 1 .

RPDmean $=[\mid$ sample $1-$ sample $2 \mid \div$ Mean $] \times 100$

where

RPDmean is the mean relative percent difference; sample 1 is the concentration in sequential replicate 1, in milligrams or micrograms per liter or colony forming units per 100 milliliters;

sample 2 is the concentration in sequential replicate 2 , in milligrams or micrograms per liter or colony forming units per 100 milliliters; and

Mean is the mean concentration in the two sequential replicates, in milligrams or micrograms per liter or colony forming units per 100 milliliters.

Additionally, two field blank samples were collected in December 2016 and May 2017 for analysis for nutrients, and one field blank sample was collected in December 2016 for analysis for pharmaceuticals, trace metals, and wastewater indicator compounds. Seven field blank samples were collected for microbial analysis throughout the course of the study. For each sampling event, a microbial field blank from each of the peristaltic and submersible sampling pumps was submitted to the MI-BaRL for analysis.

One field spike was collected at well C2 in December 2017 and sent to the NWQL for analysis for pharmaceuticals. Field spikes are environmental samples to which a known volume and concentration of analyte is added. Field spikes are used to assess bias and variability from groundwater matrix interference or degradation of organic constituents during sampling processing, storage, and analysis. 


\section{Effect of Cemetery Leachate on Groundwater Quality}

All routine water-quality data collected as part of this study are available in the USGS National Water Information System (NWIS) database at https://waterdata.usgs.gov/nwis (U.S. Geological Survey, 2017a) and quality-control data are presented in table 9 . The results of this study are presented in the following sections.

\section{Physical Characteristics of Groundwater}

Physical groundwater characteristics can be used to explain the general conditions of the groundwater that is being sampled. Nearly 68 percent of the groundwater samples collected for analysis at Mt. Hope Cemetery were collected under oxic conditions, whereas the remainder of samples were collected under anoxic conditions (dissolvedoxygen concentration less than 0.5 milligrams per liter $[\mathrm{mg} / \mathrm{L}])$ (table 4$)$. Groundwater temperatures ranged from 5.3 to $14.8{ }^{\circ} \mathrm{C}$, with warmer temperatures occurring during the July 2017 sampling event. Specific-conductance values were highest at well $\mathrm{C} 1$ and at the Fenner well, and ranged from 478 to 2,120 microsiemens per centimeter at 25 degrees Celsius $\left(\mu \mathrm{S} / \mathrm{cm}\right.$ at $\left.25^{\circ} \mathrm{C}\right)$. Groundwater $\mathrm{pH}$ was consistently neutral, with values ranging from 6.7 to 7.4 (table 4).

\section{Nutrients}

Nutrients can come from natural sources such as eroding soils, decomposing plant material, and wildlife waste, as well as point-source discharges and nonpoint sources (Brennan and others, 2015). Nonpoint sources of nutrients commonly are attributed to agricultural and urban environments; however, information on the effect of cemeteries on nutrient concentrations in groundwater is limited.

Results of this study indicate that wells $\mathrm{C} 1$ and C3 exhibited elevated total nitrogen concentrations (median 2.11 and $1.11 \mathrm{mg} / \mathrm{L}$, respectively) when compared to the Fenner well (median $0.46 \mathrm{mg} / \mathrm{L}$ ), whereas well C2 exhibited lower concentrations of total nitrogen (median $0.27 \mathrm{mg} / \mathrm{L}$ ) compared to the Fenner well. Well

Table 4. Physical characteristics of groundwater samples, Mt. Hope Cemetery, Lansing, Michigan, 2016-17.

[USGS, United States Geological Survey; E, environmental sample; R, replicate sample; B, field blank sample; S, spike sample (laboratory spike); MB, microbial field blank sample; A, age-dating sample; ft, feet; ${ }^{\circ} \mathrm{C}$, degrees Celsius; $\mathrm{mg} / \mathrm{L}$, milligrams per liter; $\mathrm{SU}$, standard units; $\mu \mathrm{S} / \mathrm{cm}$, microsiemens per centimeter at $25^{\circ} \mathrm{C}$; --, missing data]

\begin{tabular}{|c|c|c|c|c|c|c|c|c|c|}
\hline Well & $\begin{array}{c}\text { USGS } \\
\text { station number }\end{array}$ & Station name & $\begin{array}{l}\text { Sampling } \\
\text { date }\end{array}$ & $\begin{array}{c}\text { Type of } \\
\text { samples } \\
\text { collected } \\
\text { (E, R, B, } \\
\text { S, MB, A) }\end{array}$ & $\begin{array}{l}\text { Sampling } \\
\text { depth } \\
\text { (ft) }\end{array}$ & $\begin{array}{c}\text { Temperature, } \\
\text { water } \\
\left({ }^{\circ} \mathrm{C}\right)\end{array}$ & $\begin{array}{c}\text { Dissolved- } \\
\text { oxygen } \\
\text { concentration } \\
\text { (mg/L) }\end{array}$ & $\begin{array}{c}\text { pH } \\
\text { (SU) }\end{array}$ & $\begin{array}{c}\text { Specific } \\
\text { conductance } \\
(\mu \mathrm{S} / \mathrm{cm})\end{array}$ \\
\hline \multirow[t]{5}{*}{$\mathrm{C} 1$} & \multirow[t]{5}{*}{424240084314001} & \multirow{5}{*}{$\begin{array}{l}\text { 04N 02W 27A01 } \\
\text { INGHAM CO (C-1) }\end{array}$} & $12 / 7 / 2016$ & $\mathrm{E}, \mathrm{B}, \mathrm{MB}$ & -- & 11.7 & 4.9 & 6.7 & 1,020 \\
\hline & & & $1 / 25 / 2017$ & A & 8 & 7.6 & 1 & 6.8 & 1,120 \\
\hline & & & $2 / 28 / 2017$ & $\mathrm{E}$ & 3 & 7.9 & 2.1 & 6.7 & 1,030 \\
\hline & & & $5 / 23 / 2017$ & $\mathrm{E}, \mathrm{MB}$ & 9 & 10.7 & 0 & 6.7 & 1,020 \\
\hline & & & $7 / 18 / 2017$ & $\mathrm{E}, \mathrm{R}$ & 10 & 14.8 & 0.3 & 6.8 & 1,050 \\
\hline \multirow[t]{5}{*}{$\mathrm{C} 2$} & \multirow[t]{5}{*}{424230084314101} & \multirow{5}{*}{$\begin{array}{l}\text { 04N 02W 27A01 } \\
\text { INGHAM CO (C-2) }\end{array}$} & $12 / 7 / 2016$ & $\mathrm{E}, \mathrm{S}$ & 5.5 & 10.5 & 1.6 & 7.1 & 890 \\
\hline & & & $1 / 25 / 2017$ & A & 3.5 & 7.7 & 0.9 & 7.2 & 968 \\
\hline & & & $2 / 28 / 2017$ & $\mathrm{E}, \mathrm{MB}$ & 6 & 5.8 & 2.1 & 7.2 & 836 \\
\hline & & & $5 / 23 / 2017$ & $\mathrm{E}, \mathrm{R}$ & 4 & 10.3 & 0 & 7.1 & 762 \\
\hline & & & $7 / 18 / 2017$ & $\mathrm{E}, \mathrm{MB}$ & 5.5 & 14.2 & -- & 7.2 & 921 \\
\hline \multirow[t]{5}{*}{$\mathrm{C} 3$} & \multirow[t]{5}{*}{424221084313801} & \multirow{5}{*}{$\begin{array}{l}\text { 04N 02W 27A01 } \\
\text { INGHAM CO (C-3) }\end{array}$} & $12 / 7 / 2016$ & $\mathrm{E}$ & 5 & 10.2 & 2 & 7.1 & 823 \\
\hline & & & $1 / 25 / 2017$ & A & 3 & 9.2 & 0.9 & 7.1 & 793 \\
\hline & & & $2 / 28 / 2017$ & $\mathrm{E}, \mathrm{R}$ & 3 & 5.3 & 1.6 & 7 & 784 \\
\hline & & & $5 / 23 / 2017$ & $\mathrm{E}$ & -- & 8.4 & 0 & 7.2 & 478 \\
\hline & & & $7 / 18 / 2017$ & $\mathrm{E}$ & 5 & 12.2 & 0 & 7.3 & 619 \\
\hline \multirow[t]{5}{*}{ Fenner } & \multirow[t]{5}{*}{424235084311201} & \multirow{5}{*}{$\begin{array}{l}\text { 04N 02W 26BBDB } 01 \\
\text { INGHAM CO } \\
\text { (FENNER } \\
\text { ARBORETUM) }\end{array}$} & $12 / 7 / 2016$ & $\mathrm{E}, \mathrm{R}$ & 50 & 10.4 & 0.9 & 6.9 & 1,580 \\
\hline & & & $1 / 25 / 2017$ & A & 50 & 13.5 & 0.7 & 7.4 & 2,110 \\
\hline & & & $2 / 28 / 2017$ & $\mathrm{E}, \mathrm{MB}$ & 50 & 10.7 & 1.4 & 6.9 & 2,060 \\
\hline & & & $5 / 23 / 2017$ & $\mathrm{E}, \mathrm{B}, \mathrm{MB}$ & 45 & 11 & 0.7 & 6.8 & 2,120 \\
\hline & & & $7 / 18 / 2017$ & $\mathrm{E}, \mathrm{MB}$ & 50 & 11 & 0 & 7.1 & 1,300 \\
\hline
\end{tabular}


C1 exhibited elevated nitrite plus nitrate (mainly nitrate) concentrations (median $1.66 \mathrm{mg} / \mathrm{L}$ ) when compared to the other wells (median $0.01 \mathrm{mg} / \mathrm{L}$ ) and lower levels of ammonia (median $0.04 \mathrm{mg} / \mathrm{L}$ ) when compared to the Fenner well (median $0.33 \mathrm{mg} / \mathrm{L}$ ). At well C3, total phosphorus, orthophosphate, and ammonia concentrations (median $0.17,0.13$, and $0.52 \mathrm{mg} / \mathrm{L}$, respectively) greatly exceeded concentrations measured at the Fenner well (median 0.01, 0.03, and $0.33 \mathrm{mg} / \mathrm{L}$, respectively) (fig. 2). The highest nutrient concentrations were observed in December 2016 and February 2017 during periods of low precipitation. On February 28, 2017, the nitrite plus nitrate concentration at well $\mathrm{C} 1$ exceeded the total nitrogen results; this difference of $0.11 \mathrm{mg} / \mathrm{L}$ is most likely the result of method variability, as nearly all of the nitrogen in the sample was in the form of nitrate.

In a study in West Germany in 2002, groundwater was sampled at various distances from the cemetery and results indicated elevated ammonia and nitrate concentrations downgradient from the cemetery; however, the data showed rapid attenuation with distance from the cemetery (Young and others, 2002). Whereas well $\mathrm{C} 1$ indicated elevated nitrite plus nitrate concentrations when compared to the Fenner well, ammonia concentrations were lower. The opposite was true at well C3, where ammonia concentrations were higher, and nitrite plus nitrate values were lower than those in samples from the Fenner well. Nutrient-concentration distribution by well in samples collected December 2016 to July 2017 is presented in figure 2 .

\section{Trace Metals and Formaldehyde}

Until 1951, several solutions containing metals were used in the embalming process (Young and others, 2002). A variety of metals (including iron, copper, lead, and zinc) are commonly used in the construction of caskets (Spongberg and Becks, 2000), and mercury can be found in medical devices and dental fixtures. Arsenic was a common constituent in the early embalming process and, in the 1800s and early 1900 s, was used to treat diseases such as syphilis and psoriasis (American Cancer Society, 2014). Both formaldehyde and arsenic are used in historic and present-day embalming practices, are known carcinogens, and can cause other health problems. Formaldehyde usage and exposure are regulated by both the Occupational Safety and Health Administration and the EPA (Mao and Woskie, 1994).

Trace-metal concentrations in shallow groundwater potentially associated with cemetery leachate were compared to the EPA drinking-water standards and health advisory criteria (table 5). Arsenic concentrations at well $\mathrm{C} 3$ exceeded the EPA maximum contaminant level (MCL) for drinking water (10 micrograms per liter $[\mu \mathrm{g} / \mathrm{L}]$ ) (U.S. Environmental Protection Agency, 2012) on two occasions, with arsenic concentrations almost six times as high as those in the Fenner well. Concentrations of manganese at all sites, including the Fenner well, exceeded the EPA lifetime health advisory (LHA) and
EPA secondary maximum contaminant level (SMCL) in drinking water (300 and $50 \mu \mathrm{g} / \mathrm{L}$, respectively) (U.S. Environmental Protection Agency, 2012; U.S. Environmental Protection Agency, 2009a). Other than a sample collected at well C1 in February 2017, manganese concentrations from all three wells exceeded concentrations in the Fenner well, and in December 2016, manganese concentrations at wells C1, C2, and C3 were almost twice as high as concentrations in the Fenner well.

Other trace metals potentially associated with cemetery leachate were found in relatively low concentrations compared to EPA drinking-water standards, and were commonly reported as less than the reporting limit (RL) (as indicated with a "less-than" notation in table 5). Molybdenum concentrations were highest in wells $\mathrm{C} 1$ and $\mathrm{C} 2$, whereas aluminum and lead concentrations were highest in wells $\mathrm{C} 1$ and $\mathrm{C} 3$. Copper concentrations were variable, and both mercury and zinc concentrations were below the laboratory detection limit (table 5). Of the 19 metals analyzed for as part of the trace-metals analyses, concentrations were highest most frequently at wells $\mathrm{C} 1$ (8 highest concentrations of 19 different metals, or 42 percent) and C3 (5 highest concentrations of 19 metals, or 26 percent), and least frequently at the Fenner well ( 3 highest concentrations of 19 metals, or 16 percent) and well C2 (0 highest concentrations of 19 metals). Concentrations of the remaining 3 metal analytes (silver, zinc, and mercury) of the 19 metals analyzed for at the NWQL were below the RL.

Formaldehyde was not detected in any of the groundwater samples collected during this study, possibly because formalin (which is made up of a 35- to 40-percent solution of formaldehyde and water) at low concentrations under anaerobic conditions in the body can degrade to form methane, carbon dioxide, and fatty acids (Young and others, 2002).

\section{Microbial Results}

Many of the bacterial species evaluated as part of this study are known to be associated with the human gut or skin microbiome and therefore can be released through natural human decay. The influx of nutrients, as well as other organic and inorganic chemicals naturally present in the soil, may provide an environment that supports bacterial growth (Engelbrecht, 1998). As a result, bacteria may be introduced to the groundwater (Ücisik and Rushbrook, 1998).

Total coliforms, enterococci, E. coli, fecal coliforms, and staphylococci were enumerated in groundwater samples collected from the monitoring wells and the Fenner well (fig. 1). Concentrations in groundwater samples collected at the Fenner well were zero to minimal (1-12 colony forming units per 100 milliliters [CFU/100 mL], average $2.3 \mathrm{CFU} / 100 \mathrm{~mL}$ ) of total coliforms, enterococci, E. coli, fecal coliforms, and staphylococci (fig. 3). In contrast, concentrations of total coliforms, E. coli, and staphylococci were higher in samples from wells C1, C2, and C3 than in samples from the Fenner well. Broth enrichments indicate that Salmonella species (sp.) were present in all samples collected from wells $\mathrm{C} 1$ and $\mathrm{C} 2$, in three 
A. Mt. Hope monitoring well C1 (U.S. Geological Survey station number 424240084314001 )

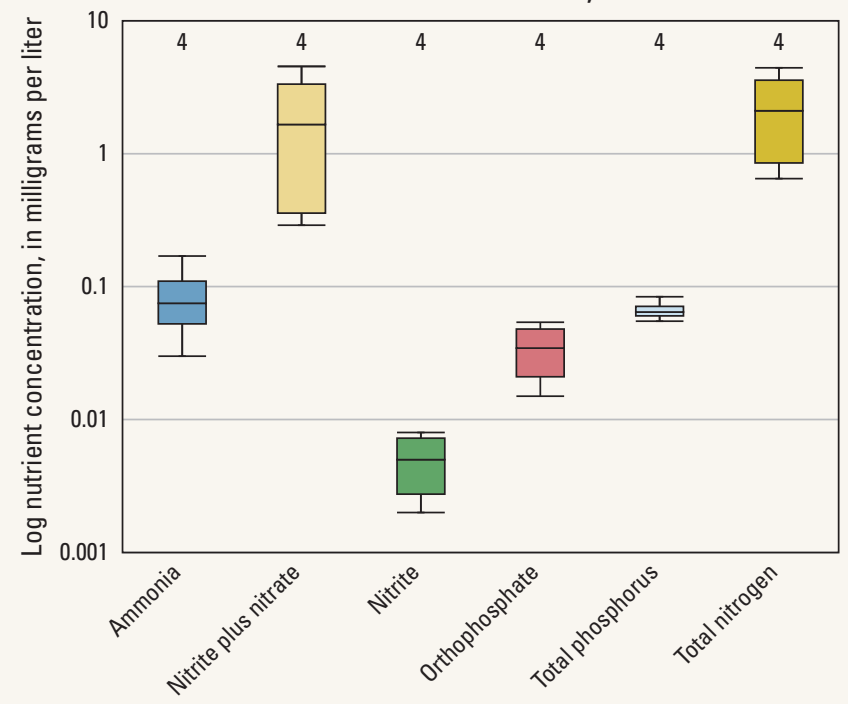

C. Mt. Hope monitoring well C3 (U.S. Geological Survey station number 424221084313801)

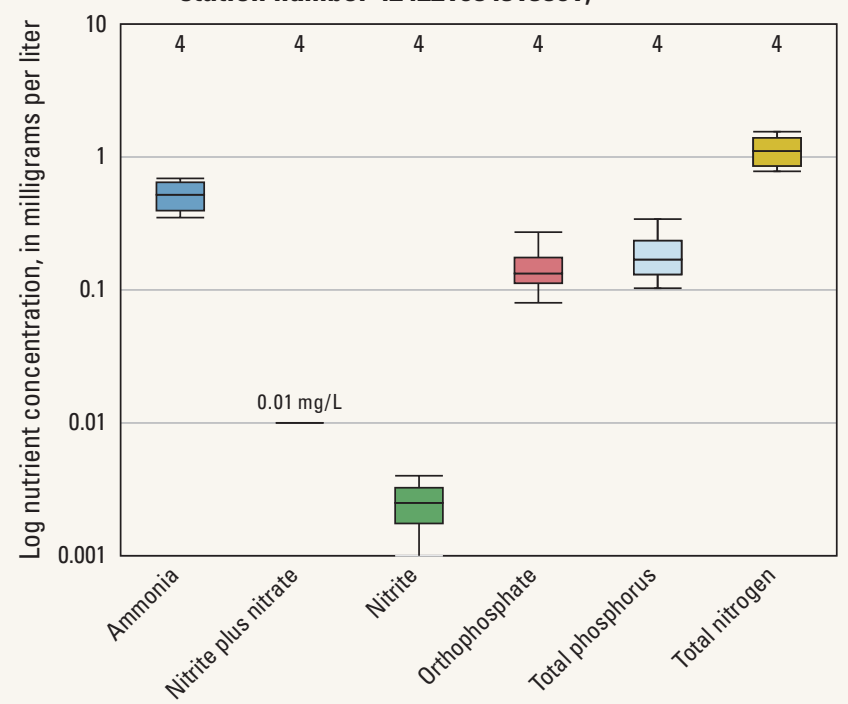

B. Mt. Hope monitoring well C2 (U.S. Geological Survey station number 424230084314101)

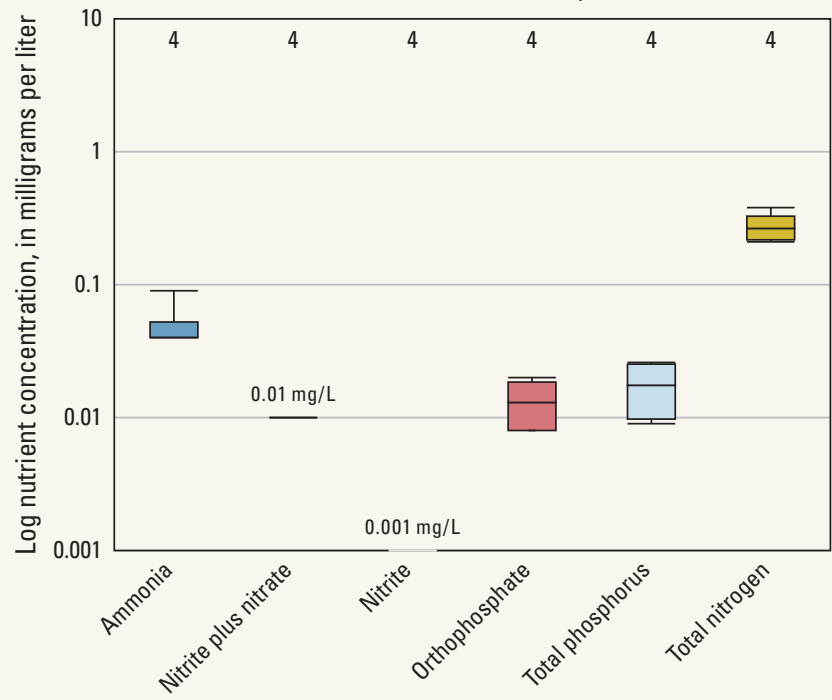

D. Mt. Hope Fenner well (U.S. Geological Survey station number 424235084311201)

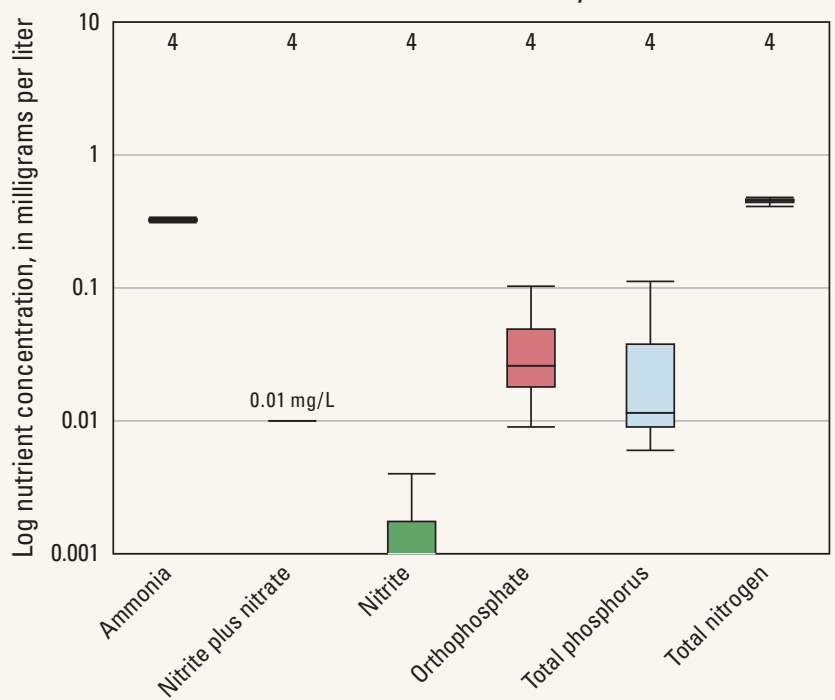

\section{EXPLANATION}

[Censored values less than the reporting limit were treated as equal to the reporting limit; $\mathrm{N}$, nitrogen; $\mathrm{P}$, phosphorus]

$4 \quad$ Number of values

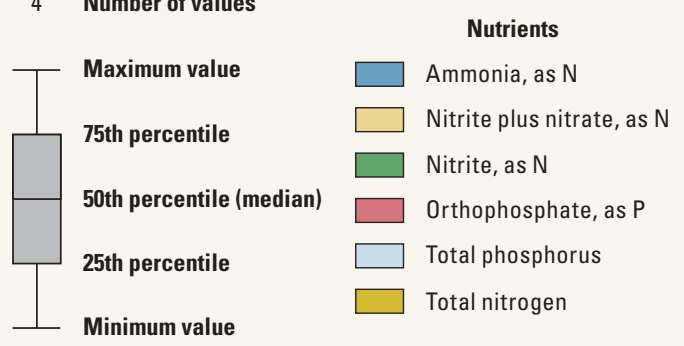

Figure 2. Distribution of nutrient concentrations in groundwater samples by well, Mt. Hope Cemetery, Lansing, Michigan, 2016-17. 
Table 5. Trace-metal concentrations in groundwater samples, Mt. Hope Cemetery, Lansing, Michigan, 2016-17, data quartiles, and U.S. Environmental Protection Agency (EPA) drinking-water standards and health-advisory criteria.

[LHA, EPA lifetime health-advisory level determined from EPA toxicity data and methods; MCL, enforceable EPA maximum contaminant level; SMCL, nonenforceable EPA secondary maximum contaminant level; DWEL, drinking-water equivalent level, which is a drinking-water lifetime exposure limit; concentrations in micrograms per liter $(\mu \mathrm{g} / \mathrm{L})$; underlined font indicates exceedances of EPA drinking-water standards; colors indicate the data quartile percentage, with the first quartile representing 0 to 25 percent of the data ( $\tan$ ), second quartile representing $>25$ to 50 percent of the data (yellow), third quartile representing $>50$ to 75 percent of the data (orange), and fourth quartile representing $>75$ to 100 percent of the data (red); $>$, greater than; <, less than; *, chemical or instrumental interference sample was diluted, which raised the reporting limit to $<9.0 \mu \mathrm{g} / \mathrm{L}$; drinking-water standards and health advisories from U.S. Environmental Protection Agency (2018)]

\begin{tabular}{|c|c|c|c|c|c|c|c|c|c|}
\hline \multirow[b]{2}{*}{ Well } & \multirow{2}{*}{$\begin{array}{c}\text { Sampling } \\
\text { date }\end{array}$} & \multicolumn{7}{|c|}{ EPA drinking-water standard } & \multirow{2}{*}{$\begin{array}{c}\begin{array}{c}\text { EPA health } \\
\text { advisory }\end{array} \\
\text { DWEL } \\
\text { Molybdenum } \\
\text { >200 }\end{array}$} \\
\hline & & $\begin{array}{c}\text { LHA } \\
\text { Manganese } \\
>300\end{array}$ & $\begin{array}{c}\text { MCL } \\
\text { Arsenic } \\
>10\end{array}$ & $\begin{array}{c}\text { MCL } \\
\text { Lead } \\
>15\end{array}$ & $\begin{array}{c}\text { MCL } \\
\text { Copper } \\
>1,300\end{array}$ & $\begin{array}{c}\text { MCL } \\
\text { Mercury } \\
>2\end{array}$ & $\begin{array}{c}\text { SMCL } \\
\text { Aluminum } \\
50 \text { to }>\mathbf{2 0 0}\end{array}$ & $\begin{array}{l}\text { SMCL } \\
\text { Zinc } \\
>5,000\end{array}$ & \\
\hline \multicolumn{10}{|c|}{ Concentration $(\mu \mathrm{g} / \mathrm{L})$} \\
\hline $\mathrm{C} 1$ & $12 / 7 / 2016$ & $\underline{1,000}$ & 2.2 & 0.07 & 0.7 & $<0.005$ & 4.4 & $<2.0$ & 3.66 \\
\hline \multirow[t]{2}{*}{$\mathrm{C} 2$} & $12 / 7 / 2016$ & $\underline{682}$ & 1.0 & 0.05 & 1.3 & $<0.005$ & $<3.0$ & $<2.0$ & 1.75 \\
\hline & $2 / 28 / 2017$ & $\underline{977}$ & 0.9 & $<0.02$ & 0.6 & $<0.005$ & $<3.0$ & $<2.0$ & 1.46 \\
\hline \multirow[t]{2}{*}{$\mathrm{C} 3$} & $12 / 7 / 2016$ & $\underline{870}$ & $\underline{22.7}$ & 0.06 & 0.4 & $<0.005$ & 17.5 & $<2.0$ & 0.92 \\
\hline & $2 / 28 / 2017$ & $\underline{594}$ & $\underline{19.0}$ & $<0.02$ & $<0.2$ & $<0.005$ & 11.8 & $<2.0$ & 0.55 \\
\hline
\end{tabular}

of the samples collected from well C3, and in only one sample collected from the Fenner well (fig. 3).

Concentrations of fecal coliforms and enterococci in samples collected from well C3 were variable. Of the three monitoring wells, $\mathrm{C} 1$ had the highest mean concentration of staphylococci (307 CFU/100 mL) and $\mathrm{C} 3$ had the highest mean concentration of $E$. coli $(64 \mathrm{CFU} / 100 \mathrm{~mL})$. Additionally, $\mathrm{C} 3$ was the only site at which concentrations of enterococci (mean $10 \mathrm{CFU} / 100 \mathrm{~mL}$ ), E. coli (mean $64 \mathrm{CFU} / 100 \mathrm{~mL}$ ), fecal coliforms (mean $59 \mathrm{CFU} / 100 \mathrm{~mL}$ ), and staphylococci (mean $192 \mathrm{CFU} / 100 \mathrm{~mL}$ ) were elevated (fig. 3).

The $E$. coli $16 \mathrm{~S}$ rDNA gene (species marker) was detected in well $\mathrm{C} 3$ throughout the course of this study (table 6). This gene was also detected in multiple samples from wells $\mathrm{C} 1$ and $\mathrm{C} 2$. Although this gene was detected during the May 2017 sampling at the Fenner well, it was also detected in the field blank associated with this site on that day; therefore, this detection could be the result of contamination. This gene was not present in any field blanks associated with well $\mathrm{C} 1, \mathrm{C} 2$, or $\mathrm{C} 3$. In addition to E. coli $16 \mathrm{~S}$ genes, two pathogen genes (shiga-toxin 1, stxl; and eaeA), and one antibiotic resistance gene marker ( $\operatorname{van} B$ ), were detected in groundwater samples from the monitoring wells $\mathrm{C} 2$ and $\mathrm{C} 3$ (table 6). The $v a n B$ gene for intermediate level of vancomycin resistance in enterococci (Enterococcus spp.) was detected in December 2016 and May 2017 at well C3 (table 6). The E. coli eaeA (intimin attachment) gene marker was also present in the sample collected at well C3 in December 2016. The E. coli stxl gene marker was present in the February 2017 replicate sample collected from well C3 and the July 2017 replicate sample collected from well $\mathrm{C} 1$; however, the gene was not present in the primary samples collected on those dates. The E. coli stx 1 gene marker also was present in the July 2017 sample collected from well C2 (table 6). Other than E. coli $16 \mathrm{~S}$, none of the targeted bacterial pathogen or antibiotic resistance genes was present in samples from the Fenner well (table 6). Presence of these pathogen and antibiotic resistance genes does not confirm pathogenicity or resistance, but does indicate that the bacteria carrying these genes have the potential to be pathogenic and resistant to antibiotics. Despite the elevated concentrations of staphylococci in groundwater samples from all monitoring wells, neither femA nor mecA gene markers (genetic markers for Staphylococcus aureus [S. aureus] and methicillin-resistant $S$. aureus [MRSA], respectively) were detected in any of our samples (table 6).

The increase in bacterial growth and presence of these genes indicate that some source of bacteria is likely affecting the groundwater quality in these monitoring wells. The presence of FIB (for example, coliforms, fecal coliforms, E. coli, and enterococci) in groundwater indicates that fecal or sewage sources may be nearby and that the potential exists for bacteria species to enter the groundwater system (Embrey and Runkle, 2006).

Results of the few studies exploring the microbial composition of cemetery leachate have shown high concentrations of bacteria in wells in and adjacent to cemeteries (Engelbrecht, 
A. Mt. Hope monitoring well C1 (U.S. Geological Survey station number 424240084314001 )



C. Mt. Hope monitoring well C3 (U.S. Geological Survey station number 424221084313801)



B. Mt. Hope monitoring well C2 (U.S. Geological Survey station number 424230084314101)

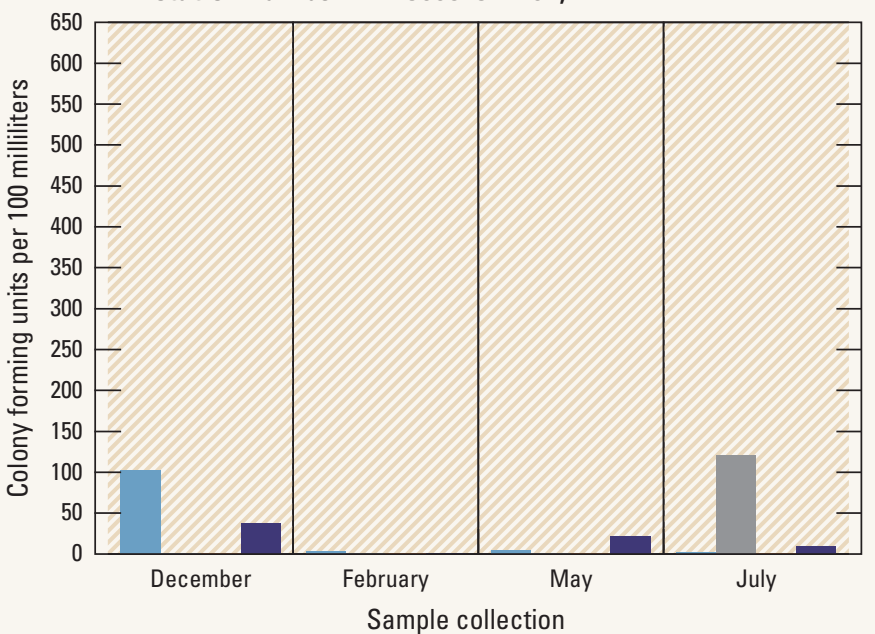

D. Mt. Hope Fenner well (U.S. Geological Survey station number 424235084311201)

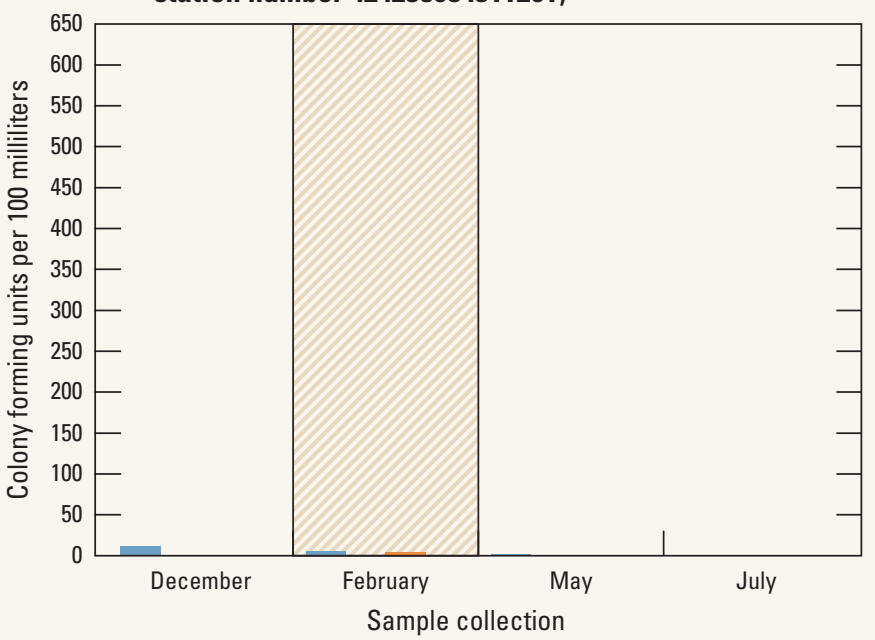

\section{EXPLANATION}

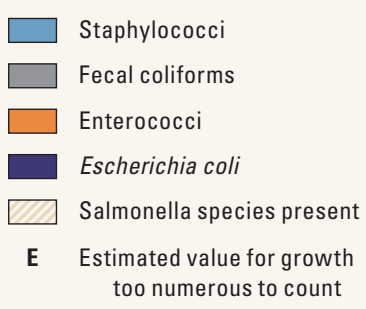

Figure 3. Concentrations of indicator bacteria in groundwater samples collected near Mt. Hope Cemetery, Lansing, Michigan, 2016-17. 
Table 6. Occurrence of microbial pathogen and antibiotic resistance genes in groundwater samples, Mt. Hope Cemetery, Lansing, Michigan, 2016-17.

[The 16S rDNA marker is an internal control indicating presence of Escherichia coli (E. coli); presence of the vanA, vanB, and mecA genes indicates potential for antibiotic resistance; all other genes indicate potential pathogenicity; - , gene absent; +, gene present (outlined in red)]

\begin{tabular}{|c|c|c|c|c|c|c|c|c|c|c|c|c|c|}
\hline \multirow{2}{*}{ Well } & \multirow{2}{*}{$\begin{array}{c}\text { Sample } \\
\text { date }\end{array}$} & \multicolumn{3}{|c|}{ Enterococcus } & \multicolumn{4}{|c|}{ E. coli } & \multicolumn{2}{|c|}{ Salmonella } & \multirow{2}{*}{$\frac{\text { Shigella }}{\text { ipaH }}$} & \multicolumn{2}{|c|}{ Staphylococcus } \\
\hline & & esp & $\operatorname{van} A$ & $\operatorname{van} B$ & $16 S$ & stx 1 & stx2 & eaeA & invA & spvC & & femA & me $c A$ \\
\hline \multirow{3}{*}{$\mathrm{C} 1$} & $12 / 7 / 2016$ & - & - & - & - & - & - & - & - & - & - & - & - \\
\hline & $5 / 23 / 2017$ & - & - & - & + & - & - & - & - & - & - & - & - \\
\hline & $7 / 18 / 2017$ & - & - & - & - & - & - & - & - & - & - & - & - \\
\hline \multirow{3}{*}{$\mathrm{C} 2$} & $2 / 28 / 2017$ & - & - & - & - & - & - & - & - & - & - & - & - \\
\hline & $5 / 23 / 2017$ & - & - & - & + & - & - & - & - & - & - & - & - \\
\hline & $7 / 18 / 2017$ & - & - & - & + & + & - & - & - & - & - & - & - \\
\hline \multirow{2}{*}{$\mathrm{C} 3$} & $12 / 7 / 2016$ & - & - & + & + & - & - & + & - & - & - & - & - \\
\hline & $2 / 28 / 2017$ & - & - & - & + & - & - & - & - & - & - & - & - \\
\hline \multirow{3}{*}{ Fenner } & $2 / 28 / 2017$ & - & - & - & - & - & - & - & - & - & - & - & - \\
\hline & $5 / 23 / 2017$ & - & - & - & + & - & - & - & - & - & - & - & - \\
\hline & $7 / 18 / 2017$ & - & - & - & - & - & - & - & - & - & - & - & - \\
\hline \multicolumn{2}{|c|}{ Number of detections } & 0 & 0 & 2 & 9 & 1 & 0 & 1 & 0 & 0 & 0 & 0 & 0 \\
\hline
\end{tabular}

1998; Ücisik and others, 1998; Rodrigues and Pacheco, 2010; Environment Agency, 2004). These studies have identified the presence of a variety of bacterial species including many found in this study, such as total coliforms, fecal coliforms, E. coli, enterococci, and staphylococci (Dent, 2002; Ücisik and Rushbrook, 1998; Trick and others, 2001).

\section{Contaminants of Emerging Concern}

Contaminants of emerging concern (CECs), including pharmaceuticals, personal care products, and wastewater indicator compounds, can be broadly defined as any synthetic or naturally occurring chemical or any microorganism that is not commonly monitored in the environment but has the potential to enter the environment and cause known or suspected adverse ecological and (or) human-health effects. These contaminants tend to be persistent, bioaccumulative, and (or) toxic to humans and the environment (U.S. Environmental Protection Agency, 2016). Data related to CECs in groundwater near cemeteries appear to be nonexistent or extremely limited.

Many CECs, including atrazine, triclosan, carbamazepine, and polybrominated diphenyl ethers (PBDEs), have been linked to endocrine disruption in wildlife and humans, yet little is known about the occurrence, transport, and fate of these contaminants, particularly as they relate to cemeteries. In recent years, PBDEs have been used as flame retardants in various applications, including textiles, plastics, furniture, and automobiles (Centers for Disease Control and Prevention, 2018).

Pharmaceuticals were not detected at concentrations above the reporting limit in any of the three monitoring wells or the Fenner well. Of the 63 wastewater indicator compounds analyzed for, 5 compounds were detected in groundwater at concentrations above their respective NWQL reporting limits (table 7). The compound 3-Methyl1H-indole (also known as skatole) is used as a fragrance, and is the source of the objectionable odor in feces and coal tar (Haack, 2009). The concentration of skatole in well C1 (table 7) exceeded the RL. Also present in well $\mathrm{C} 1$ and in well $\mathrm{C} 2$ was p-Cresol or paraCresol, which is used as a wood preservative (Haack, 2009), is present in coal tar, and is produced by bacterial fermentation in the human large intestine. Phenol, which is a component of disinfectants, mouthwash, cigarettes, and embalming fluid, was present in all three monitoring wells as well as the Fenner well. Camphor (used as a flavor, as an odorant [embalming fluid], or in ointments) was detected in well $\mathrm{C} 3$ at a concentration above the RL $(0.071 \mu \mathrm{g} / \mathrm{L})$ and in wells $\mathrm{C} 1$ and $\mathrm{C} 2$ at concentrations below the RL. Atrazine, an herbicide, was detected at a concentration above the RL in well C2 (table 7).

The presence of CECs in surface water and groundwater was evaluated in a previous USGS study (Haack, 2009) that targeted a variety of land uses in Michigan from urban to agricultural. The results of the study indicated that 8 of 129 constituents (about 6 percent) were detected in groundwater at concentrations above the laboratory RL; however, most of the 
Table 7. Contaminants of emerging concern detected in groundwater samples, Mt. Hope Cemetery, Lansing, Michigan, $2016-17$.

$[\mathrm{ng} / \mathrm{L}$, nanograms per liter; $\mu \mathrm{g} / \mathrm{L}$, micrograms per liter; <, less than; E, estimated value; *, atrazine reporting limit was increased by the laboratory as a result of contamination in the field blank; color indicates a sample concentration that exceeded the U.S. Geological Survey National Water Quality Laboratory reporting limit (outlined in red), or detection of a contaminant but at a concentration less than the reporting limit (outlined in blue)]

\begin{tabular}{|c|c|c|c|c|c|c|}
\hline Wells & Date & $\begin{array}{c}\text { Atrazine } \\
\text { (ng/L) }\end{array}$ & $\begin{array}{c}\text { Camphor } \\
\text { ( } \mu \mathrm{g} / \mathrm{L})\end{array}$ & $\begin{array}{c}\text { p-Cresol } \\
\text { ( } \mu \mathrm{g} / \mathrm{L})\end{array}$ & $\begin{array}{c}\text { Phenol } \\
\text { ( } \mu \mathrm{g} / \mathrm{L} \text { ) }\end{array}$ & $\begin{array}{c}\text { 3-Methyl-1H-indole } \\
\text { (skatole) } \\
\text { ( } \mu \mathrm{g} / \mathrm{L})\end{array}$ \\
\hline \multirow[t]{2}{*}{$\mathrm{C} 1$} & $12 / 7 / 2016$ & $<20$ & 0.024 & 0.16 & 1.06 & 0.045 \\
\hline & $2 / 28 / 2017$ & $<20$ & $<0.044$ & $<0.08$ & $<0.16$ & $<0.036$ \\
\hline \multirow[t]{2}{*}{$\mathrm{C} 2$} & $12 / 7 / 2016$ & $23 \mathrm{E}$ & $<0.044$ & $<0.08$ & 2.26 & $<0.036$ \\
\hline & $2 / 28 / 2017$ & $<28^{*}$ & $<0.044$ & $0.04 \mathrm{E}$ & $<0.16$ & $<0.036$ \\
\hline $\mathrm{C} 3$ & $2 / 28 / 2017$ & $<20$ & $<0.011$ & $<0.08$ & $<0.16$ & $<0.036$ \\
\hline \multirow[t]{2}{*}{ Fenner } & $12 / 7 / 2016$ & $<20$ & $<0.044$ & $<0.08$ & 3.99 & $<0.036$ \\
\hline & $2 / 28 / 2017$ & $<20$ & $<0.044$ & $<0.08$ & $<0.16$ & $<0.036$ \\
\hline
\end{tabular}

detections were categorized as "detected but not quantified" (Haack, 2009). For a given constituent, the number of analyses ranged from 17 to 113 . In the current study, 5 of 65 constituents (about 8 percent) were detected at concentrations above the RL; however, the number of analyses was much smaller (8, not including quality-control samples) (table 7). The five constituents detected at concentrations above the RL in the current study were not detected in the 2009 study, although some of the detections in the 2009 study were not quantifiable (Haack, 2009).

\section{Groundwater Age}

Age-dating techniques were used to determine the approximate age of groundwater that recharged the wells sampled in this study. This analysis was conducted to estimate the residence time of groundwater in the soils prior to reaching the monitoring wells. Two techniques were used to estimate groundwater ages: chlorofluorocarbon (CFC) analysis and sulfur hexafluoride $\left(\mathrm{SF}_{6}\right)$ analysis. A detailed description of the methods, assumptions, and interpretation of $\mathrm{CFC}$ and $\mathrm{SF}_{6}$ analyses can be found in Cook and Böhlke (2000) and Busenberg and Plummer (2000), respectively.

At this study location, the reducing conditions in the groundwater resulted in methanogenesis, which caused degradation of the CFC molecules. This process was evidenced by the presence of methane in the dissolved-gas samples collected as part of the age-dating groundwater sampling event. This degradation can complicate the interpretation of the analytical results and produce erroneous groundwater ages - in this case, approximately 40 to 50 years old. However, the analyses for $\mathrm{SF}_{6}$, which is not susceptible to degradation in reduced conditions, yielded ages ranging from 1 to 8 years (fig. 4). Groundwater in the Fenner well (fig. 1), also in reduced conditions, had a CFC age of 60 years (which is likely erroneous) and an $\mathrm{SF}_{6}$ age of 40 years.

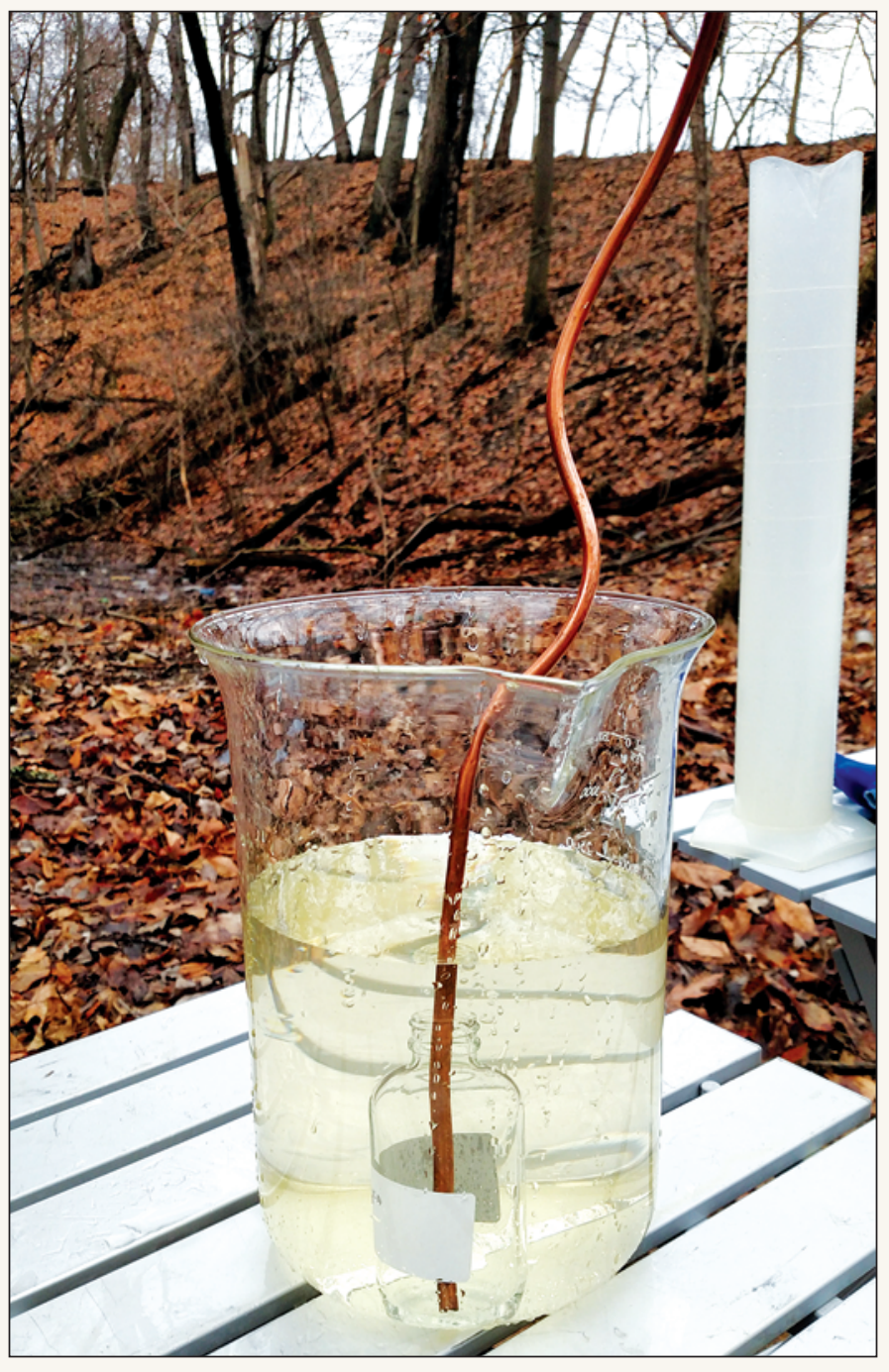

Sample bottle used for groundwater age dating is submerged in water collected from the well pump through the copper tube to avoid air contact so that results of analyses for dissolved gases can be used to help determine the age and contamination potential of the groundwater being analyzed. Photograph by Julia Prokopec, U.S. Geological Survey. 


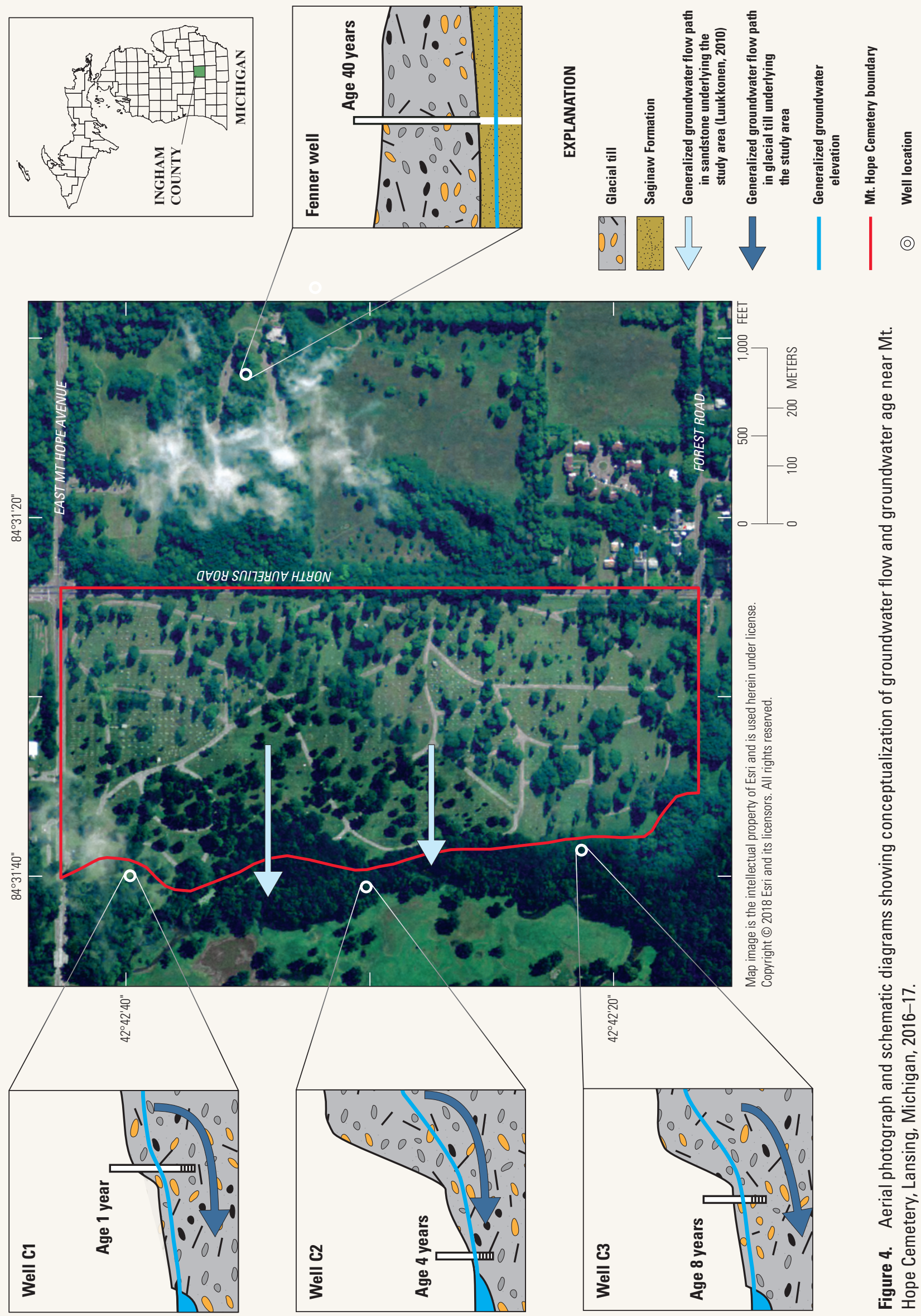




\section{Quality-Control and Quality-Assurance Results}

Relative percent difference was calculated for nutrients, metals, CECs, and FIB. Constituent pairs were excluded from the RPD analysis when one or both analyses in a constituent replicate pair were reported as less than the applicable laboratory reporting level. Relative percent differences were then calculated for the remaining replicate pairs and the results were summarized by determining the median RPD for each constituent (table 8). In four instances all of the data were censored and, therefore, the RPD was not calculated (table 8).
Relative percent differences varied depending on the constituent, an indication of variability in the number of quality-control samples collected, sample-collection method, and laboratory method. The nutrient nitrite plus nitrate had the lowest median RPD ( 0 percent), and the CEC analyte phenol had the highest RPD (84 percent), indicating greater confidence in the nitrite plus nitrate results than the phenol results (table 8).

Detections of chemical constituents in the field blank samples were minimal (table 9). Copper and lead were detected in the field blank sample collected on December 7 , 2016, at concentrations of 3.8 and $0.14 \mu \mathrm{g} / \mathrm{L}$, respectively;

Table 8. Relative percent difference in constituent concentrations for replicate samples, Mt. Hope Cemetery, Lansing, Michigan, 2016-17.

$[\mathrm{mg} / \mathrm{L}$, milligrams per liter; $<$, less than; $\mu \mathrm{g} / \mathrm{L}$, micrograms per liter; CECs, chemicals of emerging concern; E. coli, Escherichia coli; MPN, most probable number per 100 milliliters; CFU/100 mL, colony forming units per 100 milliliters; A, constituent pairs included only censored data so no relative percent difference was calculated; *, constituent pairs were excluded from the relative percent difference analysis when one or both analyses in a constituent replicate pair were reported as less than the applicable laboratory reporting level. Relative percent differences were then calculated for the remaining replicate pairs and the results were summarized by determining the median relative percent difference for each constituent]

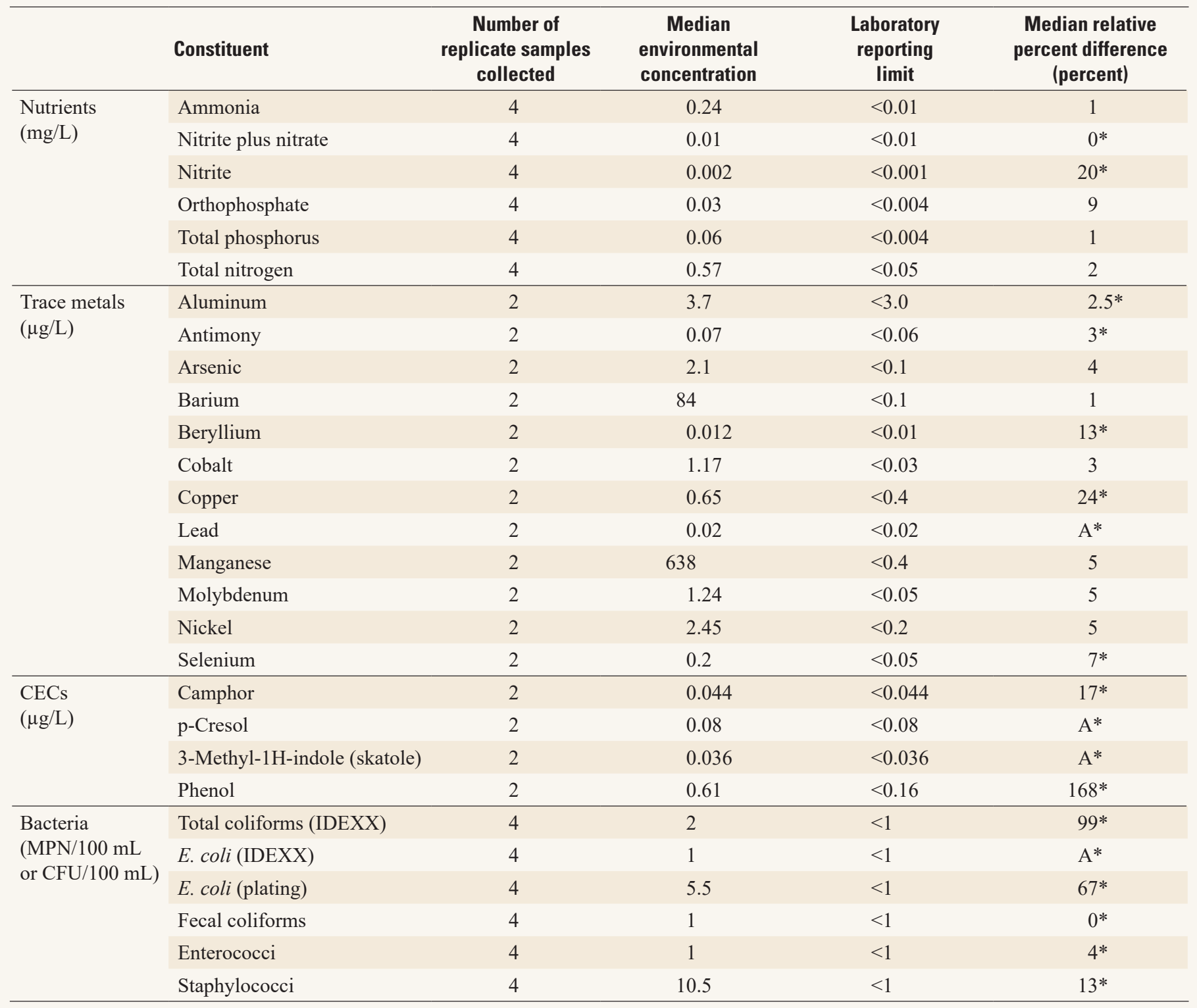


however, environmental sample concentrations on December 7, 2016, were either below the detection limit or detected at low concentrations. Phenol was detected in the field blank collected in December $2016(0.55 \mu \mathrm{g} / \mathrm{L})$ (table 9$)$, whereas phenol concentrations in the environmental samples collected in December 2016 ranged from 1.06 to $3.99 \mu \mathrm{g} / \mathrm{L}$ (table 7). No other CECs or pharmaceuticals were detected in the field blanks. Formaldehyde was not detected in any of the field blanks. The field spike results for pharmaceuticals are not presented here as no pharmaceutical compounds were detected in this study.

The field blank collected from well C1 in December 2016 showed Salmonella sp. growth (table 9). The field blank collected from well C2 in February 2017 showed presumptive $E$. coli growth on the modified membrane-thermotolerant $E$. coli mTEC selective media; however, PCR targeting the E. coli $16 \mathrm{~S}$ rDNA genetic marker did not confirm the presence of $E$. coli in this sample. The field blank collected at the Fenner well in May 2017 and July 2017 was positive for the E. coli 16S rDNA genetic marker (table 9). Laboratory blanks consisting of sterile PBS solution were processed with all environmental samples and were absent of contamination on all media except Reasoner's 2A agar (R2A).

Table 9. Quality-control sample results, Mt. Hope Cemetery, Lansing, Michigan, 2016-17.

$[\mathrm{mg} / \mathrm{L}$, milligrams per liter; $\mu \mathrm{g} / \mathrm{L}$, micrograms per liter; CECs, chemicals of emerging concern; MPN, most probable number per 100 milliliters; CFU/100 mL, colony forming units per 100 milliliters; E. coli, Escherichia coli; >, greater than; <, less than; n.d., no data; E, estimated; -, gene absent; +, gene present]

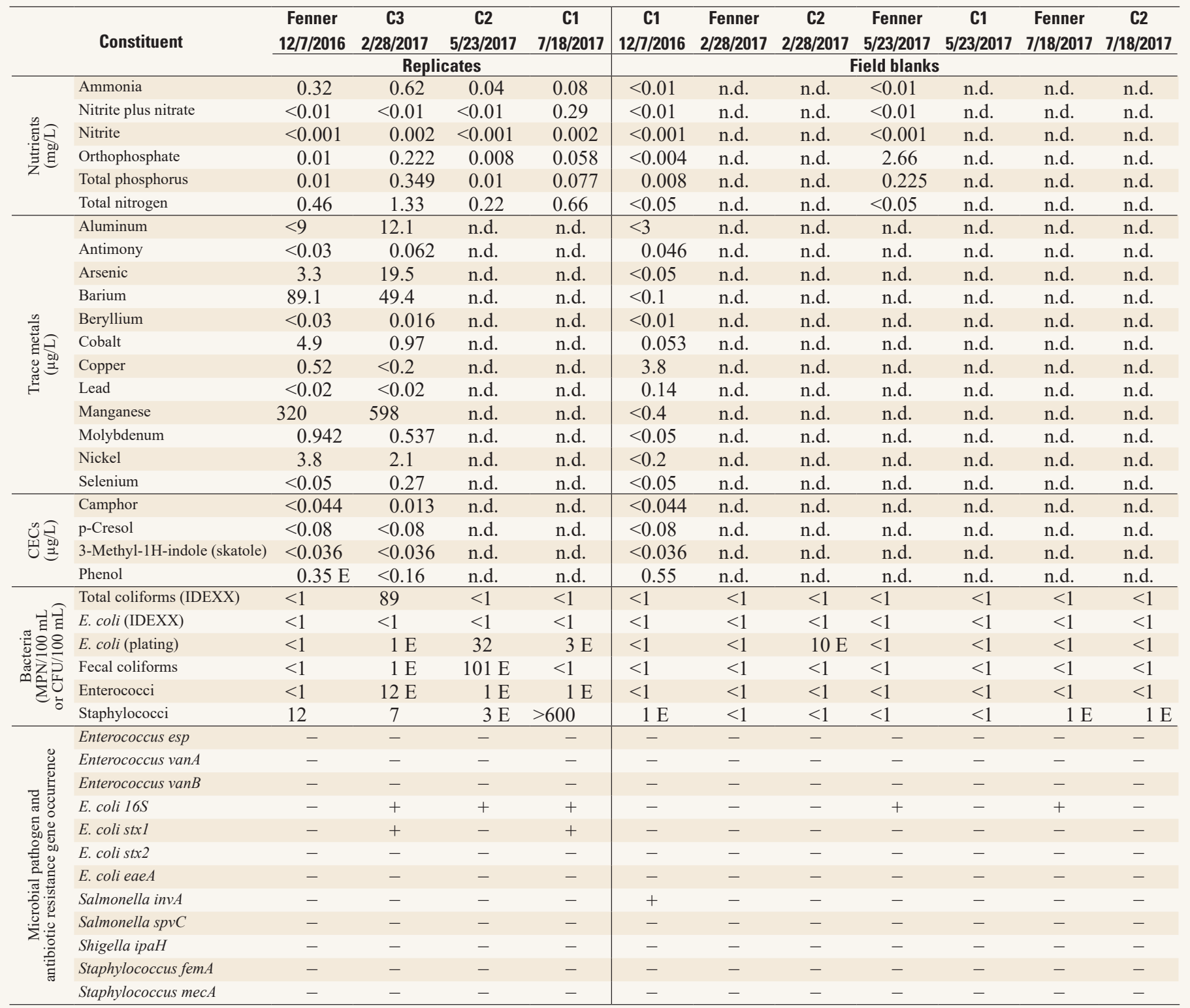




\section{Other Potential Sources of Contaminants to Cemeteries}

Other sources of background contamination can be present in cemeteries that could make interpreting a groundwater evaluation more difficult. Some cemeteries use fertilizers and insecticides to help keep the grounds green and well maintained; however, fertilizers are used only minimally at Mt. Hope Cemetery. Starter fertilizer is used in the spring to help establish grass seed on new graves established during the winter, and two markers at Mt. Hope Cemetery are fertilized and maintained by a third party (Irene Cahill, Public Services Department, City of Lansing, written commun., 2018). Also, sanitary sewers near a cemetery could be a potential source of a variety of chemical and microbial constituents through exfiltration (loss of sewage) that can occur as a result of infrastructure deterioration (Hunt and others, 2010); however, no sanitary sewer lines are located near Mt. Hope Cemetery, either at the north cemetery border at East Mt. Hope Avenue or the east cemetery border at North Aurelius Road. Another potential source of contamination to the study area is nearby Sycamore Creek, which could affect groundwater quality through surface-water/groundwater interaction. Although wells $\mathrm{C} 1$ and $\mathrm{C} 3$ are far enough from the creek that they are not likely affected by surface water (fig. 1), well C2 is near Sycamore Creek, so the potential for surface water to interact with groundwater is greater at that location. Overall, concentrations of chemical compounds and microbes in samples from well C2 were lower than those in samples from wells C1 and $\mathrm{C} 3$, one indication of possible surface-water exchange at that location even given the adjusted sampling approach of sampling only after Sycamore Creek had returned to base flow. Additionally, the presence of various animals such as deer and waterfowl was noted during sampling; although these animals are a potential source of FIB to groundwater, the amount of FIB they may contribute is unknown.

\section{Summary and Conclusions}

From December 2016 to July 2017, the U.S. Geological Survey conducted approximately quarterly groundwater sampling at three monitoring wells in Mt. Hope Cemetery, Lansing, Michigan, and at one well just east of the cemetery and outside the potential effects of cemetery leachate at Fenner Nature Center. This study included the determination of concentrations of nutrients, trace metals, formaldehyde, microbial pathogens, contaminants of emerging concern (CECs), and age-dating compounds in groundwater in and near the cemetery in an effort to determine whether cemetery leachate to groundwater, particularly in wellhead protection areas, may cause environmental or human-health concerns.

This report summarizes the analytical results from four sampling events. The small sample size did not allow for a thorough analysis of the fate and transport of constituents associated with common burial processes; however, the results can be used to determine whether evidence exists that supports the hypothesis that cemetery leachate may be a concern for water-resource management.

Distinct differences were noted between analysis results for the monitoring wells and those for the Fenner well. First, samples from wells $\mathrm{C} 1$ and $\mathrm{C} 3$ contained elevated concentrations of nutrients, particularly total nitrogen and nitrite plus nitrate at well $\mathrm{C} 1$ and total nitrogen, ammonia, phosphorus, and orthophosphate at well C3. Second, concentrations of manganese and molybdenum generally were higher in samples from the monitoring wells than in those from the Fenner well, especially at well $\mathrm{C} 1$, and concentrations of arsenic and aluminum at well $\mathrm{C} 3$ were higher than those at the Fenner well. Third, elevated microbial growth, including that of total coliforms, fecal coliforms, E. coli, enterococci, staphylococci, and Salmonella spp., was found in all three monitoring wells compared to the Fenner well. Potential pathogen or antibiotic resistance genes were detected in samples from the three monitoring wells, but not in those from the Fenner well. The amount of bacterial growth and presence of these bacterial pathogen genes indicate that a source of bacteria is affecting the quality of the water in these monitoring wells. Additionally, most of the CECs detected at concentrations above the reporting limit were in samples from wells $\mathrm{C} 1, \mathrm{C} 2$, and C3. These study results are similar to results of studies conducted in Canada, Australia, and the United Kingdom in which elevated concentrations of bacteria, metals, and nutrients were found in cemetery leachate.

This preliminary investigation demonstrates that cemetery leachate may affect shallow groundwater quality at this study location; however, further research is warranted to determine the extent of this effect. The results of this study indicate the potential for cemeteries to affect local water resources and, if cemeteries are located in wellhead protection areas, understanding the extent of potential contamination may be critical. In Michigan, cemeteries currently are not included in the contaminant source inventory that lists sites within the Wellhead Protection Area that may have the potential to contaminate drinking water.

Future monitoring efforts might include longer term groundwater monitoring to account for factors such as seasonal variation in contaminant loading to groundwater, the relation between contaminant loading and precipitation events, and the relation between contaminant loading and distance from the source. Other future areas of research could include investigating the role of hydrogeologic settings in contaminant loading from cemeteries, analyzing groundwater flow paths, and researching the interaction of groundwater with surface water and the potential for cemetery leachate to contaminate surface water. Also in this study, high concentrations of staphylococci were found in the monitoring wells; further research is needed to determine the bacterial species (for example, Staphylococcus aureus or Staphylococcus epidermis) and source of these bacteria in the monitoring wells. Furthermore, 
no information has been published on the presence of pathogen or antibiotic resistance genes in cemetery leachate. The detection of these genes in the monitoring wells in this study indicates that more research is needed to determine the source, transport, and fate of these genes within this environment, as well as the relation between biogeochemical settings and bacterial viability and transport to groundwater. In the United States, data on the effect of cemeteries on water quality are limited; therefore, a larger scale assessment of cemeteries would be useful to inform decision making with respect to regional, or national, changes in cemetery management.

Results of this study indicate that cemeteries may be a potential source of chemical and microbial contamination to nearby groundwater and surface water. Additional research would inform the efforts of managers of cemetery facilities on best practices to protect water resources.

\section{References Cited}

American Cancer Society, 2014, Arsenic and cancer risk: American Cancer Society web page, accessed February 16, 2018, at http://www.cancer.org/cancer/cancercauses/othercarcinogens/intheworkplace/arsenic.

American Public Health Association, 2012, Standard methods for the examination of water and wastewater ( $22 \mathrm{~d}$ ed.), Methods 9222G, 9223B, 9213D: Washington, D.C., APHA, American Water Works Association, and Water Environment Federation, $1496 \mathrm{p}$.

Brennan, A.K., Hoard, C.J., Duris, J.W., Ogdahl, M.E., and Steinman, A.D., 2015, Water quality and hydrology of Silver Lake, Oceana County, Michigan, with emphasis on lake response to nutrient loading, 2012-14: U.S. Geological Survey Scientific Investigations Report 2015-5158, 75 p. [Also available at https://doi.org/10.3133/sir20155158.]

Brenner, E., 2014, Human body preservation-Old and new techniques: Journal of Anatomy, v. 224, no. 3, p. 316-344, https://doi.org/10.1111/joa.12160.

Busenberg, E., and Plummer, L.N., 2000, Dating young ground water with sulfur hexafluoride-Natural and anthropogenic sources of sulfur hexafluoride: Water Resources Research, v. 36, no. 10, p. 3011-3030, accessed May 14, 2018, at https://doi.org/10.1029/2000WR900151.

Centers for Disease Control and Prevention, 2017, National Biomonitoring Program: Centers for Disease Control and Prevention web page, accessed February 16, 2018, at http:// www.cdc.gov/biomonitoring.
Chiu, C.H., and Ou, J.T., 1996, Rapid identification of Salmonella serovars in feces by specific detection of virulence genes, invA and $s p v C$, by an enrichment broth culture-multiplex PCR combination assay: Journal of Clinical Microbiology, v. 34, no. 10, p. 2619-2622, accessed May 14, 2018, at http://jcm.asm.org/content/34/10/2619.full.pdf + html.

Cook, P.G., and Böhlke, J.K., 2000, Determining timescales for groundwater flow and solute transport, in Cook, P.G., and Herczeg, A.L., eds., Environmental tracers in subsurface hydrology: Boston, Mass., Springer, p. 1-30, accessed July 23, 2018, at https://doi.org/10.1007/978-14615-4557-6_1.

Dent, B.B., and Knight, M.J., 1998, Cemeteries-A special kind of landfill, in Proceedings of the International Association of Hydrogeologists, Sustainable Solutions Conference, February 8-13, 1998, Melbourne, Australia, Kenilworth, p. 451-456.

Dent, B.B., 2002, The hydrogeological context of cemetery operations and planning in Australia, volume 1: Sydney, Australia, The University of Technology, $453 \mathrm{p}$.

Duris, J.W., Haack, S.K., and Fogarty, L.R., 2009, Gene and antigen markers of Shiga-toxin producing E. coli from Michigan and Indiana river water-Occurrence and relation to recreational water quality criteria: Journal of Environmental Quality, v. 38, no. 5, p. 1878-1886.

Dutka-Malen, S., Evers, S., and Courvalin, P., 1995, Detection of glycopeptide resistance genotypes and identification to the species level of clinically relevant enterococci by PCR: Journal of Clinical Microbiology, v. 33, no. 1, p. 24-27.

Embrey, S.S., and Runkle, D.L., 2006, Microbial quality of the Nation's ground-water resources, 1993-2004: U.S. Geological Survey Scientific Investigations Report 2006-5290, $34 \mathrm{p}$.

Engelbrecht, J.F.P., 1998, Groundwater pollution from cemeteries, in Water Institute of Southern Africa Biennial Conference and Exhibition, Cape Town, South Africa, 1998, Proceedings: Cape Town, South Africa, Water Institute of South Africa, v. 1, p. 1-8.

Environment Agency, 2004, Assessing the groundwater pollution potential of cemetery developments: Almondsbury, Bristol, 20 p., accessed May 13, 2018, at http://www.tgmscemeteries.co.uk/download-attachment/128.

Fagan, P.K., Hornitzky, M.A., Bettelheim, K.A., and Djordjevic, S.P., 1999, Detection of Shiga-like toxin (stx1 and stx2), intimin (eaeA), and enterohemorrhagic Escherichia coli (EHEC) hemolysin (EHEC hlyA) genes in animal feces by multiplex PCR: Applied and Environmental Microbiology, v. 65, no. 2, p. 868-872. 
Farrand, W.R., and Bell, D.L., 1982, Quaternary geology of Southern Michigan: Ann Arbor, Michigan, Department of Geological Sciences, University of Michigan, scale 1:500,000, [Also available at https://ngmdb.usgs.gov/ Prodesc/proddesc_71889.htm].

Gannon, V.P., King, R.K., Kim, J.Y., and Thomas, E.J., 1992, Rapid and sensitive method for detection of Shiga-like toxin-producing Escherichia coli in ground beef using the polymerase chain reaction: Applied and Environmental Microbiology, v. 58, no. 12, p. 3809-3815.

Haack, S.K., 2009, Antibiotic, pharmaceutical, and wastewater-compound data for Michigan, 1998-2005: U.S. Geological Survey Scientific Investigations Report 2009-5217, $36 \mathrm{p}$.

Hunt, R.J., Borchardt, M.A., Richards, K.D., and Spencer, S.K., 2010, Assessment of sewer source contamination of drinking water wells using tracers and human enteric viruses: Environmental Science \& Technology, v. 44, no. 20 , p. $7956-7963$.

Islam, M.S., Hasan, M.K., Miah, M.A., Sure, G.C., Felsenstein, A., Venkatesan, M., Sack, R.B., and Albert, M.J., 1993, Use of the polymerase chain reaction and fluorescent-antibody methods for detecting viable but nonculturable Shigella dysenteriae type 1 in laboratory microcosms: Applied and Environmental Microbiology, v. 59, no. 2 , p. 536-540.

Lilley, B.D., and Brewer, J.H., 1953, The selective antibacterial action of phenylethyl alcohol: Journal of the American Pharmaceutical Association (Scientific ed.), v. 42, no. 1, p. 6-8.

Luukkonen, C.L., 2010, Model refinement and simulation of groundwater flow in Clinton, Eaton, and Ingham Counties, Michigan: U.S. Geological Survey Scientific Investigations Report 2009-5244, 53 p.

Luukkonen, C.L., 2014, Delineation of contributing areas to selected wells in Ingham County, Michigan: U.S. Geological Survey Open-File Report 2014-1054, 11 p., accessed May 13, 2018, at https://doi.org/10.3133/ofr20141054.

Mao, C., and Woskie, S., 1994, Formaldehyde use reduction in mortuaries: The Toxics Use Reduction Institute, Technical Report no. 24, University of Massachusetts, Lowell, Massachusetts, $25 \mathrm{p}$.

Mehrotra, M., Wang, G., and Johnson, W.M., 2000, Multiplex PCR for detection of genes for Staphylococcus aureus enterotoxins, exfoliative toxins, toxic shock syndrome toxin 1 , and methicillin resistance: Journal of Clinical Microbiology, v. 38 , no. 3, p. 1032-1035.
Michigan Department of Environmental Quality, 2006, Teaming up for quality drinking water-The Michigan Wellhead Protection Program Guide: Michigan Department of Environmental Quality, Drinking Water \& Environmental Health Section, 12 p., accessed January 26, 2018, at https:// www.michigan.gov/documents/deq/deq-wb-dwehs-swpuwhpguidebook_256483_7.pdf.

Reasoner, D.J., and Geldreich, E.E., 1985, A new medium for the enumeration and subculture of bacteria from potable water: Applied and Environmental Microbiology, v. 49, no. 1, p. 1-7.

Reischl, U., Linde, H.J., Metz, M., Leppmeier, B., and Lehn, N., 2000, Rapid identification of methicillin-resistant Staphylococcus aureus and simultaneous species confirmation using real-time fluorescence PCR: Journal of Clinical Microbiology, v. 38, no. 6, p. 2429-2433.

Rodrigues, L., and Pacheco, A., 2010, Groundwater contamination from cemeteries - Cases of study: Environmental 2010 - Situation and perspective for the European Union, May 6-10, 2003, Porto, Portugal, Paper C 03, 6 p., accessed May 13, 2018, at http://www.waylandwells.info/wp-content/ uploads/2012/07/Groundwater-Contamination-from-Cemeteries-Case-Studies-2010.pdf.

Shankar, V., Baghdayan, A.S., Huycke, M.M., Lindahl, G., and Gilmore, M.S., 1999, Infection-derived Enterococcus faecalis strains are enriched in esp, a gene encoding a novel surface protein: Infection and Immunity, v. 67, no. 1, p. 193-200.

Spongberg, A.L., and Becks, P.M., 2000, Inorganic soil contamination from cemetery leachate: Water, Air, and Soil Pollution, v. 117, no. 1-4, p. 313-327, accessed January 22, 2018, at https://doi.org/10.1023/A:1005186919370.

Trick, J.K., Klinck, B.A., Coombs, P., Chambers, J., Noy, D.J., West, J., and Williams, G.M., 2001, Pollution potential of cemeteries-Impact of Danescourt Cemetery, Wolverhampton: British Geological Survey Internal Report IR/01/104, vol. 29, p. 1-26.

Ücisik, A.S., and Rushbrook, P., 1998, The impact of cemeteries on the environment and public health-An introductory briefing: Copenhagen, Denmark, WHO Regional Office for Europe, $11 \mathrm{p}$.

U.S. Environmental Protection Agency, 2009a, National Primary Drinking Water Regulations: EPA 816-F-09-004, 7 p., accessed February 9, 2018, at https://www.epa.gov/sites/ production/files/2016-06/documents/npwdr_complete_table. pdf. 
U.S. Environmental Protection Agency, 2009b, Method 1600: Enterococci in water by membrane filtration using membrane-Enterococcus Indoxyl- $\beta$-D-Glucoside agar (mEI): EPA-821-R-09-016, Office of Water (4303T), Washington, D.C., U.S. Environmental Protection Agency, Office of Water, 24 p., 2 app.

U.S. Environmental Protection Agency, 2012, 2012 Edition of the Drinking Water Standards and Health Advisories: Washington, D.C., U.S. Environmental Protection Agency, Office of Water, EPA 822-S-12-001, 12 p., accessed February 9, 2018, at https://nepis.epa.gov/Exe/ZyPDF.cgi/P100N01H. PDF?Dockey=P100N01H.PDF.

U.S. Environmental Protection Agency, 2014a, Pesticide registration-Label Review Manual, chap. 2, 9 p., accessed March 27, 2018, at https://www.epa.gov/pesticide-registration/label-review-manual.

U. S. Environmental Protection Agency, 2014b, Method 1603-Escherichia coli (E. coli) in water by membrane filtration using modified membrane-thermotolerant Escherichia coli agar (modified mTEC): EPA 821-R-14-010, Office of Water (4303-T), Washington, D.C., 23 p., 2 app.

U.S. Environmental Protection Agency, 2016, Contaminants of emerging concern including pharmaceuticals and personal care products: U.S. Environmental Protection Agency web page, accessed February 16, 2018, at https://www.epa.gov/ wqc/contaminants-emerging-concern-including-pharmaceuticals-and-personal-care-products.

U.S. Environmental Protection Agency, 2018, 2018 Edition of the drinking water standards and health advisories tables: U.S. Environmental Protection Agency, Office of Water, Washington, D.C., EPA 822-F-18-001, March 2018, accessed July 24, 2018, at https:/www.epa.gov/sites/production/files/2018-03/documents/dwtable2018.pdf.

U.S. Geological Survey, 2006, Collection of water samples (ver. 2.0): U.S. Geological Survey Techniques of WaterResources Investigations, book 9, chap. A4, September 2006, accessed September 4, 2018, at http://pubs.water. usgs.gov/twri9A4/.

U.S. Geological Survey, 2017a, National Water Information System - Web interface: U.S. Geological Survey web page, accessed May 31, 2017, at https://doi.org/10.5066/ F7P55KJN.

U.S. Geological Survey, 2017b, The Reston Groundwater Dating Laboratory-Welcome: U.S. Geological Survey web page, accessed February 5, 2018, at https://water.usgs.gov/ $\mathrm{lab} /$.

Vanlier, K.E., Wood, W.W., and Brunett, J.O., 1973, Watersupply development and management alternatives for Clinton, Eaton, and Ingham Counties, Michigan: U.S. Geological Survey Water-Supply Paper 1969, 111 p.
Vassiliadis, P., Trichopoulos, D., Kalandidi, A., and Xirouchaki, E., 1978, Isolation of salmonellae from sewage with a new procedure of enrichment: Journal of Applied Bacteriology, v. 44, no. 2, p. 233-239.

Wilde, F.D., ed., 2004, Cleaning of equipment for water sampling (ver. 2.0): U.S. Geological Survey Techniques of Water-Resources Investigations, book 9, chap. A3, April 2004, accessed September 4, 2018, at http://pubs.water. usgs.gov/twri9A3/.

Wilde, F.D., Radtke, D.B., Gibs, Jacob, and Iwatsubo, R.T., eds., 2004 with updates through 2009, Processing of water samples (ver. 2.2): U.S. Geological Survey Techniques of Water-Resources Investigations, book 9, chap. A5, April 2004, accessed September 4, 2018, at http://pubs.water. usgs.gov/twri9A5/.

Young, C.P., Blackmore, K.M., Leavens, A., and Reynolds, P.J., 2002, Pollution potential of cemeteries: Environment Agency, Rio House, Almondsbury, Bristol, R\&D Project Record P2/024/1, 105 p. 

For additional information, contact:

Director, Upper Midwest Water Science Center

U.S. Geological Survey

6520 Mercantile Way, Suite 5

Lansing, MI 48911

or visit our website at:

https://mi.water.usgs.gov/

Publishing support provided by the West Trenton Publishing Service Center 
wist

ix $x y^{2}$

orited

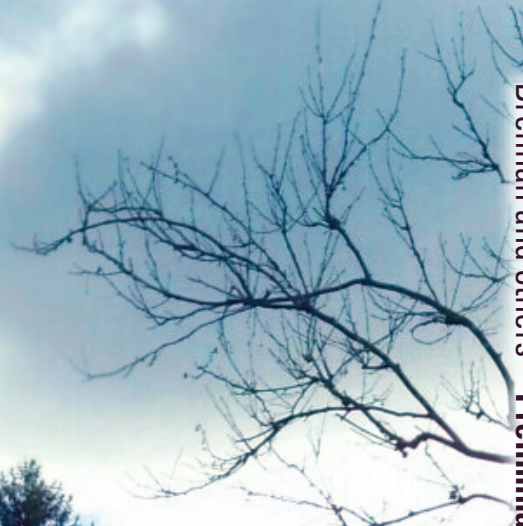

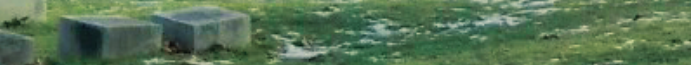

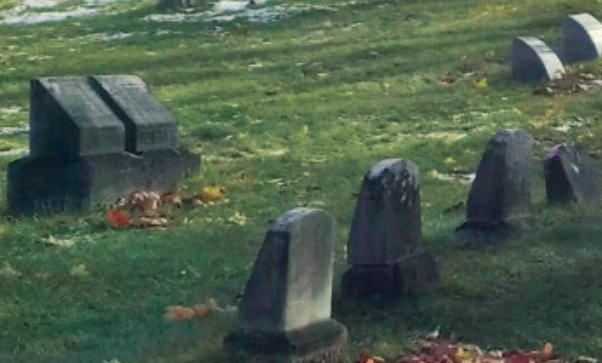

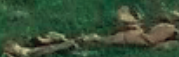

ons nes



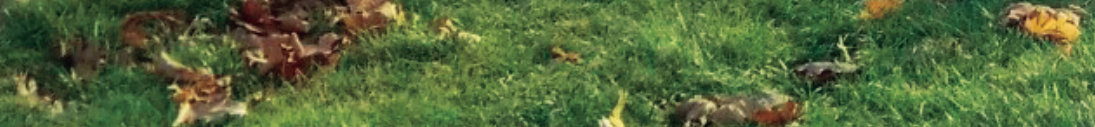

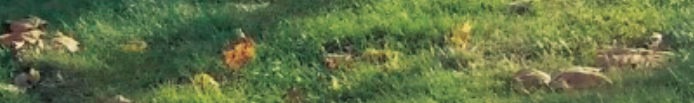

$-\infty-\infty$

coryane:

可

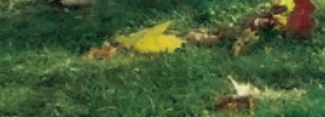



1.7. 